Pavel G. Panin ${ }^{*}$, Svetlana N. Timireva', Tatyana D. Morozova', Andrey A. Velichko ${ }^{1(t)}$

${ }^{1}$ Institute of Geography, Russian Academy of Sciences, Moscow, Russia

*Corresponding author: pgpanin@igras.ru

\title{
MICROMORPHOLOGY OF THE LATE AND MIDDLE PLEISTOCENE PALEOSOLS OF THE CENTRAL EAST EUROPEAN PLAIN
}

\begin{abstract}
In this paper we focused on the micromorphology of the Late and Middle Pleistocene paleosols exposed in twelve loess-paleosol sequences sections in the central part of the East European Plain. Each studied paleosol complex known as Mesin (MIS 5), Kamenka (MIS 6 (8) - 7 (9)), and Inzhavino (MIS 8 (10) - 9 (11)) pedocomplexes (PCS) consists typically of two members, the earlier - main - phase of the soil development taking place during an interglacial, and the later one - at the subsequent interstadial time. Interglacial paleosols formation is associated with the thermal optimum of climatic macrocycles and corresponds to conditions close to modern in the territory under consideration. Interstadial paleosols formation characterizes the intervals within the glacial period, accompanied by an increase in heat and moisture. However, the heat supply of such intervals did not reach modern level in this region (Velichko and Morozova 2015). As follows from the analysis of the soil micromorphology over the studied area, the soil microstructure experienced notable changes under changing latitudinal zonality. During the interglacial periods clay coatings and Fe-Mn pedofeatures dominated the soil microfabric; in the south loesspaleosol sequences coatings are in negligible quantities, Fe-Mn pedofeatures decrease in amount, and carbonate pedofeatures appear instead. In the microfabric of the interstadial paleosols, Fe-Mn pedofeatures are abundant, but unlike interglacial paleosols, the coatings are rare. Basically, the coatings are humus-clayey in composition, but in the more southern sections coatings are absent.
\end{abstract}

KEY WORDS: Loess, loess-paleosol sequences, interglacial, interstadial, morphology, soil, climate

CITATION: Pavel G. Panin, Svetlana N. Timireva, Tatyana D. Morozova, Andrey A. Velichko (2019) Micromorphology of the Late and Middle Pleistocene paleosols of the central East European Plain. Geography, Environment, Sustainability, Vol.12, No 1, p. 34-62 DOI-10.24057/2071-9388-2018-32

\section{INTRODUCTION}

The central part of the East European Plain is known as one of the main loess regions (Velichko and Khalcheva 1982; Velichko et al. 1994, 2006; Haase et al. 2007). In the sequences loess alternate with paleosols. Principal phases of the paleosol formation fall in interglacials (MIS 5e; 7 (9); 9 (11)); later on, as the climate became cooler, vegetation changed accordingly and interstadial soils (MIS 5c (5); 6; 8) developed (Velichko et al. 2007). The soil formation process practically stopped during the ice ages, and the loess accumulated on the 
soil surface. So loess-paleosol sequences (LPS) record and keep information of the soils of past epochs (Velichko and Morozova 2015; Zykin and Zykina 2015; Sycheva and Khokhlova 2016; Sedov et al. 2016; Tabor et al. 2017; Costantini 2017; Panin et al. 2018). Quite a number of studies were aimed at the paleosol sequences on the East European Plain (Morozova 1981; Bolikhovskaya 1995; Velichko 2002; Rusakov and Korkka 2004; Dlussky 2007; Panin 2007; Glushankova 2008; Sycheva et al. 2017; a.o.). The multidisciplinary approach used in those studies (including analyses of the soil morphology and micromorphology, paleomagnetic characteristics, physical and chemical properties, pollen analysis, etc) provided a possibility of reconstructing landscapes and climates of the past. Attempts at reconstructing soils of the Mikulino, Kamenka, and Likhvin interglacials and of the Bryansk Interstadial were made by Morozova (1995), Velichko (2002) and Dlussky (2001, 2007). The authors, however, did not pay much attention to changes in paleosols under conditions of changing soil zonality in the interglacial and interstadial periods.

In paper we focus the attention on the micromorphology of the Late and Middle Pleistocene paleosols. The micromorphological studies of paleosols make it possible to recognize specific features of the soil structure at the micro-level (Matvishina 1982; Bronger and Heinkele 1989; Bronger et al. 1998; Nettleton et al. 2000; Kemp 1999; Kemp 2013; a.o.). In particular, that approach permits to identify pedofeatures of $\mathrm{Ca}$, Fe and $\mathrm{Mn}$, and also other features that may be interpreted as manifestations of certain soil-forming processes (Gerasimova et al. 1992; Fedoroff et al. 2010). Together with physical-chemical characteristics and description of the paleosol morphology, the study of the micromorphology provided an insight into the type of soil formation and made it possible to reconstruct the paleosols of the central East European Plain in the Late and Middle Pleistocene. The purpose of this work is to identify changes in the microstructure and other micromorpho- logical features of paleosols in different latitudinal zones of the soil cover of the center of the East European Plain in the Late and Middle Pleistocene.

\section{MATERIALS AND METHODS}

The present work is based on the materials of the Middle and Late Pleistocene paleosols studied in comparison with today's soils existing in the central East European Plain. The sections considered here (Fig. 1) were analyzed by the authors of this paper and partly published in their earlier works. Among the sections, are Gololobovo (Panin 2007; Panin 2015; Little et al. 2002; Chizhikova et al. 2007), Ozherelye and Mikhnevo (Panin 2007), Suvorotino (Panin 2007), Bogolyubovo (Velichko et al. 1996), Likhvin (Little et al. 2002), Bryansk and Arapovichi (Velichko and Morozova 1963; Morozova 1981), Korostelyovo (Velichko 2002), Sebryakovo-Mikhailovka (Velichko et al., 2006), Gun'ki (Velichko et al. 1997) and Strelitsa-2017. In those sections the Late Pleistocene (Mezin paleosol complex, PC) and Middle Pleistocene (Kamenka PC and Inzhavino PC) paleosols were exposed together with the surface soils.

Here we use the latest variant of the chronostratigraphic scheme (Table 1) as suggested by A.A. Velichko and his colleagues (Velichko and Morozova 2015; Velichko et al. 2011). There exists, however, another variant of correlation between stratigraphic horizons and the marine isotope stages, also in wide use (Velichko and Morozova 2010). According to it, the Romny paleosol is correlated with MIS 7, and paleosols of Kamenka and Likhvin interglacials - with MIS 9 and MIS 11 respectively.

The sections are exposed in the brickyard quarries or cut in steep valley slopes where surface soils are present Greyzemic Phaeozems, Haplic and Calcic Chernozems. The modern soils in many quarries have been stripped away; some sections in valley scarps are often devoid of the upper humus horizons (sections Bogolyubovo and Gololobovo). 


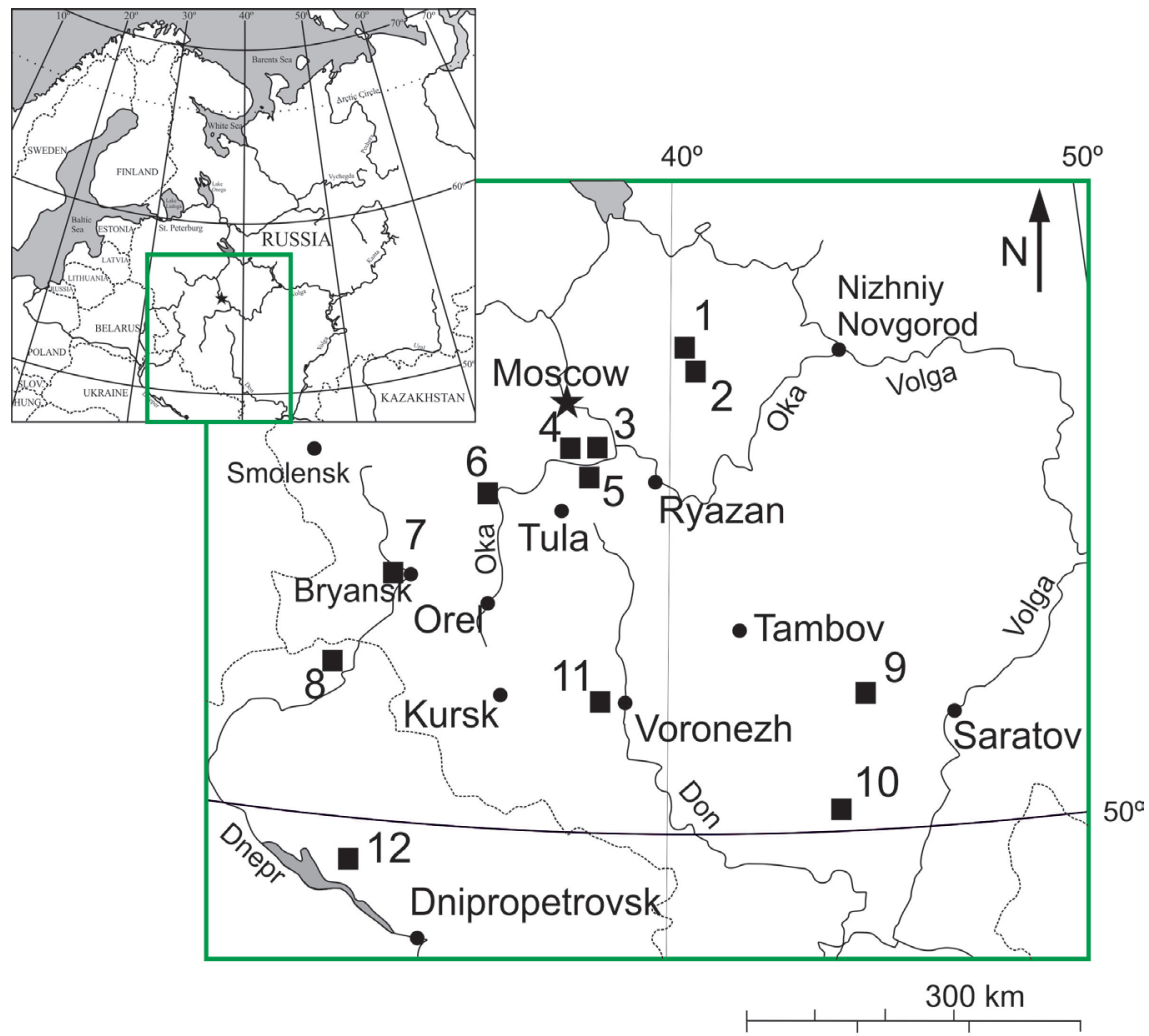

Sale 1:18 $000000 \mathrm{~km}$

Fig. 1. Position of the studied sections

Table 1. Chronostratigraphic scheme of the East European Plain (Velichko and Morozova 2010; Velichko and Morozova 2015; Velichko et al. 2011)

\begin{tabular}{|c|c|c|c|c|c|}
\hline \multirow{2}{*}{ Ice ages } & \multirow{2}{*}{\multicolumn{2}{|c|}{ East European loess region }} & \multicolumn{2}{|c|}{ MIS } & \multirow{2}{*}{$\begin{array}{c}\text { Age of } \\
\text { paleosol, ka }\end{array}$} \\
\hline & & & variant 1 & variant 2 & \\
\hline \multicolumn{3}{|c|}{ Holocene } & 1 & 1 & $\sim 11.7$ \\
\hline \multirow{7}{*}{$\begin{array}{l}\text { Valday } \\
\text { Glaciation }\end{array}$} & \multicolumn{2}{|c|}{ Altynovo loess } & \multirow{3}{*}{2} & \multirow{3}{*}{2} & - \\
\hline & \multicolumn{2}{|c|}{ Trubchevsk paleosol } & & & - \\
\hline & \multicolumn{2}{|c|}{ Desna loess } & & & - \\
\hline & \multicolumn{2}{|c|}{ Bryansk paleosol } & 3 & 3 & $\sim 25-32$ \\
\hline & \multicolumn{2}{|c|}{ Khotylevo loess } & 4 & 4 & - \\
\hline & \multirow{3}{*}{$\begin{array}{c}\text { Mezin } \\
\text { paleosol } \\
\text { complex }\end{array}$} & $\begin{array}{c}\text { Krutitsa interstadial } \\
\text { paleosol }\end{array}$ & $5 c$ & \multirow{2}{*}{5} & $\sim 98-105$ \\
\hline & & Sevsk loess & $5 d$ & & - \\
\hline $\begin{array}{c}\text { Mikulino } \\
\text { Interglacial }\end{array}$ & & $\begin{array}{l}\text { Salyn interglacial } \\
\text { paleosol }\end{array}$ & $5 e$ & $5 e$ & $\sim 117-135$ \\
\hline
\end{tabular}




\begin{tabular}{|c|c|c|c|c|c|}
\hline \multirow{7}{*}{$\begin{array}{l}\text { Dnieper } \\
\text { Glaciation }\end{array}$} & \multicolumn{2}{|c|}{ Moscow loess } & \multirow{7}{*}{6} & \multirow{3}{*}{6} & - \\
\hline & \multicolumn{2}{|c|}{ Kursk interstadial paleosol } & & & - \\
\hline & \multirow{3}{*}{$\begin{array}{l}\text { Dnieper } \\
\text { loess }\end{array}$} & Loess & & & - \\
\hline & & $\begin{array}{c}\text { Romny (?) } \\
\text { interstadial paleosol }\end{array}$ & & 7 & - \\
\hline & & Orchik (?) loess & & \multirow{3}{*}{8} & - \\
\hline & \multirow{3}{*}{$\begin{array}{c}\text { Kamenka } \\
\text { paleosol } \\
\text { complex }\end{array}$} & $\begin{array}{l}\text { Late Kamenka } \\
\text { interstadial paleosol (?) }\end{array}$ & & & - \\
\hline & & Loess & & & - \\
\hline $\begin{array}{l}\text { Kamenka } \\
\text { (Chekalin) } \\
\text { Interglacial }\end{array}$ & & $\begin{array}{c}\text { Early Kamenka } \\
\text { interglacial paleosol }\end{array}$ & 7 & 9 & $\sim 200-250$ \\
\hline \multirow{3}{*}{$\begin{array}{l}\text { Pechora } \\
\text { Glaciation }\end{array}$} & \multicolumn{2}{|c|}{ Borisoglebsk loess } & \multirow{3}{*}{8} & \multirow{3}{*}{10} & - \\
\hline & \multirow{3}{*}{$\begin{array}{c}\text { Inzhavino } \\
\text { paleosol } \\
\text { complex }\end{array}$} & $\begin{array}{l}\text { Late Inzhavino } \\
\text { interstadial paleosol }\end{array}$ & & & - \\
\hline & & Loess & & & - \\
\hline $\begin{array}{l}\text { Likhvin } \\
\text { Interglacial }\end{array}$ & & $\begin{array}{c}\text { Early Inzhavino } \\
\text { interglacial paleosol }\end{array}$ & 9 & 11 & $\sim 380-410$ \\
\hline Oka Glaciation & & Oka loess & $\begin{array}{l}10 \\
11 \\
12\end{array}$ & 12 & - \\
\hline
\end{tabular}

During the field survey a detailed morphological description (Rozanov 2004) of every section was performed along with sketching, taking photographs, and sampling. Samples for physical and chemical analyses and for micromorphological studies have been taken from every genetic horizon at 15-20 cm intervals. In order to properly interpret the fossil soil genesis, the surface soils were also sampled with the aim of a comparison with samples from paleosols.

Earlier investigations resulted in acquiring abundant materials on physical-chemical characteristics and micromorphological data that gave us an insight into the development, structure, and properties of paleosols, both interstadial and interglacial ones (Velichko and Morozova 1963; Velichko and Morozova 1972; Velichko and Morozova 2010; Velichko et al. 1985; Panin 2007; Panin 2015). It follows from the results obtained that the interstadial paleosols both of Late and Middle Pleistocene developed under grass steppe vegetation under conditions of lesser heat supply than those formed during interglacials. Typically, the interglacial paleosols formed under forests (Velichko and Morozova 2015).

The paleosol micromorphology was studied in thin sections ( $<30 \mu \mathrm{m}$ thick) impregnated with polysynthetic resin. In describing thin sections and interpreting the soil formation processes we followed the techniques described in literature (Gerasimova et al. 1992; Gerasimova et al. 2011). Thin sections were photographed under a polarized-light microscope Motic BA310Pol at 4X/0.1 magnification. The paper includes descriptions of micromorphology and photographs for sections Gololobovo, Mikhnevo, Ozherelye and Sebryakovo-Mikhailovka, where both studied paleosols and surface soils. 
Along with the investigation of the micromorpholology and morphology, the following components were determined a in the paleosols: organic carbon, obtained using wet combustion technique developed by Tyurin (Rastvorova et al. 1995); amorphous iron compounds, by Tamm's method (Tamm 1922), and non-silicate iron compounds, by Mehra and Jackson (1960). All the analyses were performed in the Chemical Analytical Laboratory, Institute of Geography, Russian Academy of Sciences.

The genetic horizons in soil profiles are marked in accordance to the FAO (2006) (Table 2). The names of the surface soils and paleosols are given in according of the IUSS Working Group WRB 2014 (2015).

\section{RESULTS}

Table 2 presents the surface soils and buried paleosols and gives information on their thickness, contents of organic carbon and their soil profile. LPS include several PC of the Late and Middle Pleistocene age. The greatest assortment of paleosols (besides the surface soil) was found in the Strelitsa-2017 section. There have been recorded a well pronounced Bryansk (MIS 3) and Romny (MIS 6 or 7) paleosols, as well as Mezin, Kamenka, Inzhavino, and Voronskiy PCs (MIS

Table 2. Characteristics of the modern soils and paleosols studied in the LPS sections

\begin{tabular}{|c|c|c|c|c|}
\hline $\begin{array}{l}\text { Section } \\
\text { number } \\
\text { (see Fig. 1) }\end{array}$ & $\begin{array}{l}\text { Names of sections } \\
\text { (coordinates of the } \\
\text { location of the sections) }\end{array}$ & Soil profile & $\begin{array}{l}\text { Soil profile } \\
\text { thickness, m }\end{array}$ & $\begin{array}{l}\text { Organic carbon } \\
\text { content in upper } \\
\text { horizons max, \% }\end{array}$ \\
\hline \multicolumn{5}{|c|}{ Surface soil (Holocene) - MIS 1} \\
\hline 1 & $\begin{array}{c}\text { Suvorotino } \\
\left(56^{\circ} 13^{\prime} 08 » N, 40^{\circ} 27^{\prime} 08^{\prime \prime} E\right)\end{array}$ & $A-E B t-B t-B C$ & 1.45 & 1.76 \\
\hline 2 & $\begin{array}{c}\text { Bogolyubovo } \\
\left(56^{\circ} 12^{\prime} 22^{\prime \prime} \mathrm{N}, 40^{\circ} 33^{\prime} 00^{\prime \prime} \mathrm{E}\right)\end{array}$ & Btp-Bt1-Bt2 & 1.50 & no data \\
\hline 3 & $\begin{array}{c}\text { Gololobovo } \\
\left(55^{\circ} 2^{\prime} 49^{\prime \prime} \mathrm{N}, 38^{\circ} 35^{\prime} 29^{\prime \prime} \mathrm{E}\right)\end{array}$ & Btp-Bt-BCt & 2.75 & 0.30 \\
\hline 4 & $\begin{array}{c}\text { Mikhnevo } \\
\left(55^{\circ} 7^{\prime} 03^{\prime \prime} \mathrm{N}, 37^{\circ} 59^{\prime} 06^{\prime \prime} \mathrm{E}\right)\end{array}$ & Ap-EBt-Bt-BCk & 1.33 & 1.03 \\
\hline 5 & $\begin{array}{c}\text { Ozherelye } \\
\left(54^{\circ} 48^{\prime} 37^{\prime \prime} \mathrm{N}, 38^{\circ} 17^{\prime} 54^{\prime \prime} \mathrm{E}\right)\end{array}$ & $A p-A E-B t$ & 1.15 & 0.32 \\
\hline 6 & $\begin{array}{c}\text { Likhvin } \\
\left(54^{\circ} 6^{\prime} 19^{\prime \prime} \mathrm{N}, 36^{\circ} 15^{\prime} 26^{\prime \prime} \mathrm{E}\right)\end{array}$ & Ap-ABt-Bt-BCk & 3.12 & 2.38 \\
\hline 7 & $\begin{array}{c}\text { Bryansk } \\
\left(53^{\circ} 13^{\prime} 14^{\prime \prime} \mathrm{N} ; 34^{\circ} 20^{\prime} 53^{\prime \prime} \mathrm{E}\right)\end{array}$ & A-Bt1-Bt2-Bt3-BC & 1.25 & 2.03 \\
\hline 8 & $\begin{array}{c}\text { Arapovichi } \\
\left(51^{\circ} 56^{\prime} 52^{\prime \prime} \mathrm{N}, 33^{\circ} 19^{\prime} 01^{\prime \prime} \mathrm{E}\right)\end{array}$ & $O-A-B-B C-C$ & 1.50 & 0.70 \\
\hline 9 & $\begin{array}{c}\text { Korostelyovo } \\
\left(51^{\circ} 50^{\prime} 28^{\prime \prime} \mathrm{N}, 42^{\circ} 24^{\prime} 58^{\prime \prime} \mathrm{E}\right)\end{array}$ & O-A-ABk-Bk & 1.68 & 3.92 \\
\hline 10 & $\begin{array}{l}\text { Sebryakovo-Mikhailovka } \\
\left(50^{\circ} 07^{\prime} 02^{\prime \prime} \mathrm{N}, 43^{\circ} 12^{\prime} 46^{\prime \prime} \mathrm{E}\right)\end{array}$ & $A-A B-B k-B C k$ & 1.95 & 1.85 \\
\hline 11 & $\begin{array}{c}\text { Strelitsa-2017 } \\
\left(51^{\circ} 37^{\prime} 15^{\prime \prime} \mathrm{N}, 38^{\circ} 54^{\prime} 09^{\prime \prime} \mathrm{E}\right)\end{array}$ & $A p-B k-B C k$ & 0.84 & no data \\
\hline 12 & $\begin{array}{c}\text { Gun'ki } \\
\left(49^{\circ} 14^{\prime} 32^{\prime \prime} \mathrm{N}, 33^{\circ} 34^{\prime} 15^{\prime \prime} \mathrm{E}\right)\end{array}$ & $A-B k$ & 0.40 & 1.16 \\
\hline
\end{tabular}




\begin{tabular}{|c|c|c|c|c|}
\hline \multicolumn{5}{|c|}{ Mezin paleosol complex (Late Pleistocene) } \\
\hline \multicolumn{5}{|c|}{ Krutitsa interstadial paleosol - MIS 5c } \\
\hline 1 & Suvorotino & A@ & 0.30 & 0.19 \\
\hline 2 & Bogolyubovo & ABg@ & 0.45 & 0.59 \\
\hline 3 & Gololobovo & A@ & 0.75 & 0.27 \\
\hline 5 & Ozherelye & A@ & 0.22 & 0.25 \\
\hline 6 & Likhvin & Al@-Bh & 0.35 & 0.38 \\
\hline 7 & Bryansk & A@1-A@2-AE & 0.20 & 0.37 \\
\hline 8 & Arapovichi & Ak@-A@ & 0.70 & 1.40 \\
\hline 9 & Korostelyovo & Aks@ & 0.65 & 0.59 \\
\hline 10 & Sebryakovo-Mikhailovka & A@ & 0.54 & no data \\
\hline 11 & Strelitsa-2017 & Ak@-ABk & 1.15 & no data \\
\hline 12 & Gun'ki & A@ & 0.80 & 0.70 \\
\hline \multicolumn{5}{|c|}{ Salyn interglacial paleosol - MIS 5e } \\
\hline 1 & Suvorotino & E-Bt-BC & 1.20 & 0.15 \\
\hline 2 & Bogolyubovo & E@-Bt & 0.30 & no data \\
\hline 3 & Gololobovo & AE@-E-Bt & 0.35 & 0.12 \\
\hline 5 & Ozherelye & ABt@-Bt & 0.23 & 0.22 \\
\hline 6 & Likhvin & AE@-B1@-Bg & 0.85 & 0.50 \\
\hline 7 & Bryansk & EB-Bt@-Bt-BC & 2.40 & 0.04 \\
\hline 8 & Arapovichi & $\begin{array}{c}\text { EBt@-Btk1-Btk2- } \\
\text { BCt }\end{array}$ & 2.20 & 0.45 \\
\hline 9 & Korostelyovo & $A B k-B C k$ & 0.99 & 0.43 \\
\hline 10 & Sebryakovo-Mikhailovka & Ay@-By & 1.88 & 0.58 \\
\hline 11 & Strelitsa-2017 & Ak@-Bk & 1.62 & no data \\
\hline 12 & Gun'ki & Bk & 1.10 & 0.46 \\
\hline \multicolumn{5}{|c|}{ Kamenka paleosol complex (Middle Pleistocene) } \\
\hline \multicolumn{5}{|c|}{ Late Kamenka interstadial paleosol - MIS 6 (8) } \\
\hline 3 & Gololobovo & A@ & 0.35 & 0.21 \\
\hline 5 & Ozherelye & A@ & 0.22 & 0.10 \\
\hline
\end{tabular}




\begin{tabular}{|c|c|c|c|c|}
\hline 4 & Mikhnevo & A@ & $<0.10$ & no data \\
\hline 9 & Korostelyovo & A@ & 1.10 & 0.55 \\
\hline 10 & Sebryakovo-Mikhailovka & A@ & 0.81 & 0.25 \\
\hline 11 & Strelitsa-2017 & A@ & 0.12 & no data \\
\hline 12 & Gun'ki & A@ & 0.90 & 0.29 \\
\hline \multicolumn{5}{|c|}{ Early Kamenka interglacial paleosol - MIS 7 (9) } \\
\hline 3 & Gololobovo & EBt-Bt & 1.40 & 0.11 \\
\hline 4 & Mikhnevo & Bt@ & 0.78 & 0.25 \\
\hline 5 & Ozherelye & EBt-Bt & 2.30 & 0.09 \\
\hline 6 & Likhvin & Btg-BCg1-BCg2 & 0.85 & 0.27 \\
\hline 9 & Korostelyovo & $A-B k$ & 0.77 & 0.43 \\
\hline 10 & Sebryakovo-Mikhailovka & $B-B C$ & 1.27 & 0.17 \\
\hline 11 & Strelitsa-2017 & $\begin{array}{c}A @-A B-B k-B C k- \\
B C\end{array}$ & 2.03 & no data \\
\hline 12 & Gun'ki & Bk & 1.20 & 0.07 \\
\hline \multicolumn{5}{|c|}{ Inzhavino paleosol complex (Middle Pleistocene) } \\
\hline \multicolumn{5}{|c|}{ Late Inzhavino interstadial paleosol - MIS 8 (10) } \\
\hline 3 & Gololobovo & A@ & 0.37 & 0.16 \\
\hline 5 & Ozherelye & A@ & 0.35 & 0.17 \\
\hline 9 & Korostelyovo & Ak@1-Ak@2 & 0.94 & 0.39 \\
\hline 10 & Sebryakovo-Mikhailovka & Ak@ & 1.04 & 0.38 \\
\hline 11 & Strelitsa-2017 & Ak@ & 0.14 & no data \\
\hline \multicolumn{5}{|c|}{ Early Inzhavino interglacial paleosol - MIS 9 (11) } \\
\hline 3 & Gololobovo & E@-Bt1-Bt2 & 1.95 & 0.05 \\
\hline 5 & Ozherelye & EBt-Bt & 0.60 & 0.10 \\
\hline 6 & Likhvin & Et@-Bt@-BC-BCg & 1.95 & 0.27 \\
\hline 9 & Korostelyovo & $\mathrm{Bk} 1-\mathrm{Bk} 2$ & 0.90 & 0.25 \\
\hline 10 & Sebryakovo-Mikhailovka & Bk & 0.42 & 0.17 \\
\hline 11 & Strelitsa-2017 & A@-E-Bg & 0.30 & no data \\
\hline
\end{tabular}


13-15). In the Bogolyubovo section (northern part of the loess zone) there are found the Bryansk paleosol and Mezin PC only.

The majority of studied sections - Suvorotino, Bogolyubovo, Gololobovo, Mikhnevo, Ozherelye, Likhvin, Bryansk and Arapovichi - are within the limits of the latitudinal zone of Greyzemic Phaeozems soils, while a few other localities feature Haplic and Calcic Chernozems. As seen in Table 2, in Greyzemic Phaeozems the maximum content of organic carbon is $2.03 \%$, in the latitudinal zone of Haplic and Calcic Chernozems the maximum is 3.92\%.

In the Mikhnevo section coatings are extremely rare in the humus horizon of Greyzemic Phaeozems. The micromorphology of horizons Bt abounds typically in clayey and humus-clayey coatings (Fig. $2 \mathrm{a}, \mathrm{b})$, both the coating size and organic carbon content increasing downwards. Pedofeatures of Fe-Mn composition are seen in horizon EBt (Fig. 2C, d). In the Sebryakovo-Mikhailovka section Chernozems the groundmass of the humus horizon is well aggregated. Thin sections of horizon Bk display pale yellowish - brown color, aggregate structure; there are carbonate nodules (Fig. 2e, f). Horizon BCk is noted for carbonate nodules increasing sharply in number (Fig. 2g, h).

\section{The Late Pleistocene Mezin paleosol complex}

There are two paleosols in the sequence representing the Mezin PC: the Krutitsa interstadial and Salyn interglacial ones. The Krutitsa interstadial soil consists mostly of humus horizons ( $A$ and $A B$ ) and is no more than $1 \mathrm{~m}$ thick. The soil thickness is slightly greater in the south of the East European Plain (0.54 to $0.80 \mathrm{~m}$ in sections Korostelyovo, Sebryakovo-Mikhailovka, Gun'ki) and does not exceed $0.70 \mathrm{~m}$ farther north (see Table 2). The paleosol is mostly described as brownish-gray loam of crumby structure. The Salyn interglacial paleosol consists of horizons $A B, A E, E$, and $B t$, the total thickness of the soil reaching $2.4 \mathrm{~m}$ (Bryansk section). The Salyn soil is mostly composed of loam and sandy loam with crumby and angular to subangular blocky structure, brown and bright-brown in color. Albic horizon is present as separate whitish lenses of sandy loam. The Krutitsa paleosol is distinguished for a high organic carbon content (up to 1.40\%). In the Salyn interglacial paleosol the organic carbon content is less than in the Krutitsa one and does not exceed $0.58 \%$.

In the interstadial Krutitsa paleosol of Ozherelye section hypo-coatings and coatings located in pores are mostly humus-clay in composition (Fig. 3a, b) and large granular aggregates (Fig. 3c, d). In Sebryakovo-Mikhailovka section there are no coatings, while Fe and Fe-Mn nodules appear instead (Fig. 3e). The humus horizon microstructure is well aggregated. Similar granular aggregates are seen as in the interstadial paleosol of the Gololobovo section, only of a smaller size (Fig. 3f). Large diamond-shaped and ungeometrical crystals (Fig. 3g, h) are distinctly seen, which is typical for gypsum pedofeatures (Kubiena 1938; Gerasimova et al. 1992; Poch et al. 2010). The transitional horizon between the interstadial and interglacial paleosols is free of gypsum. Gypsum pedofeatures are characteristic for paleosols of the Mezin PC in the southern sections of the Azov Sea (Panin et al. 2018).

The microstructure of the Salyn interglacial paleosol sampled in the Gololobovo section (horizon AE@) features large grains of quartz (Fig. 4a) and the appearance of granular aggregates (Fig. 4b). B-fabric of the groundmass is speckled and crystallitic. Albic horizons contain Fe nodules. In the horizon Bt the coatings are mostly of humus-clay composition (Fig. 4c). They are usually of compact structure, dark brown or yellow color, are mostly confined to pores. In the Sebryakovo-Mikhailovka section small-size Fe-Mn nodules occur in horizon Ay@ (Fig. 4d, e). Pedofeatures of gypsum (Fig. 4f, g) and carbonate (Fig. 4h) were recorded in the horizons Ay and By of the interglacial paleosol. 

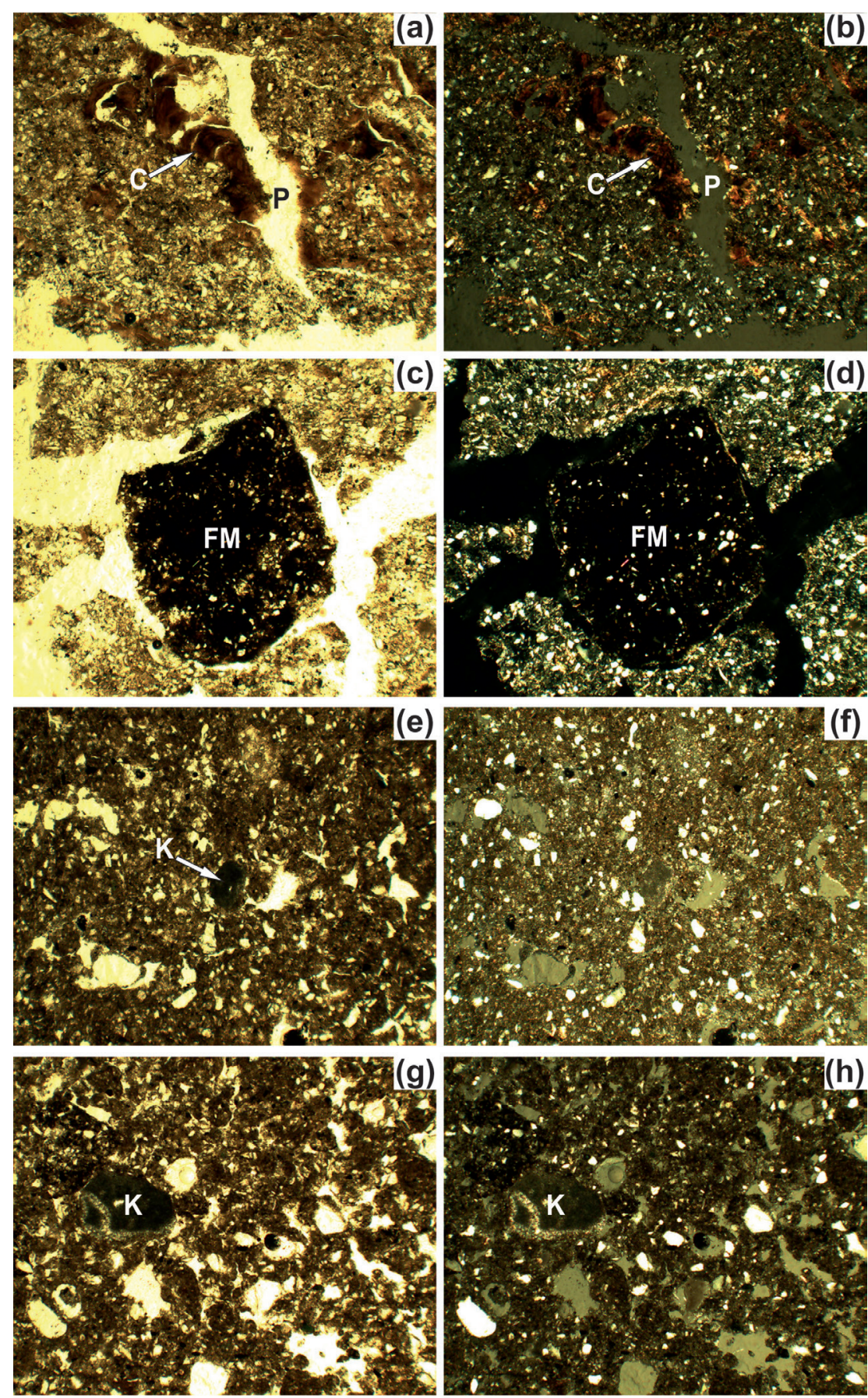

Scale $1 \mathrm{~mm}$

Fig. 2. Micromorphology of the surface soil: a - the horizon Bt, Mikhnevo section $(\mathrm{PPL}) ; \mathrm{b}$ - the same (XPL); $\mathrm{c}$ - the horizon EBt, Mikhnevo section (XPL); $\mathrm{d}$ - the same $(\mathrm{XPL})$; e - the horizon Bk, Sebryakovo-Mikhailovka section (PPL); $f$ - the same (XPL); $g$ - the horizon BCk, Sebryakovo-Mikhailovka section (PPL); $h$ - the same (XPL). Symbols in the figures: $\mathrm{C}$ - coating, $\mathrm{P}$ - plane, $\mathrm{FM}$ - Fe-Mn pedofeatures, $\mathrm{K}$ - carbonate nodule 

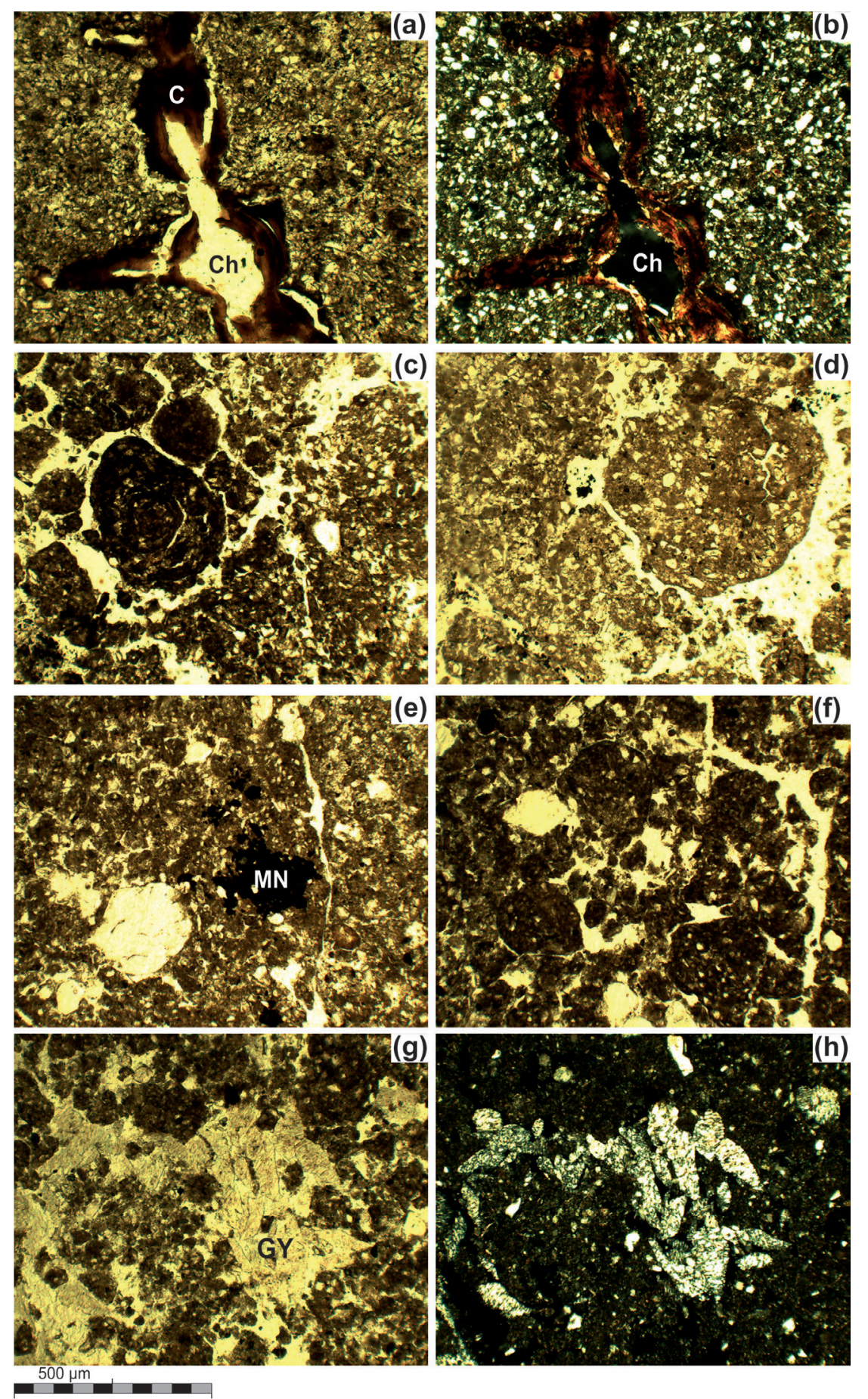

Fig. 3. Micromorphology of the Krutitsa interstadial paleosol: a - the horizon A@, Ozherelye section (PPL); $b$ - the same (XPL); $c$, $d$ - the horizon A@, Gololobovo section $(P P L) ; e, f, g-t h e$ horizon A@, Sebryakovo-Mikhailovka section (PPL); $h$ - the horizon A@, Sebryakovo-Mikhailovka section (XPL). Symbols in the figures: $\mathrm{C}$ - coating, $\mathrm{Ch}$ channel, MN - Mn pedofeatures, GY - gypsum pedofeatures 

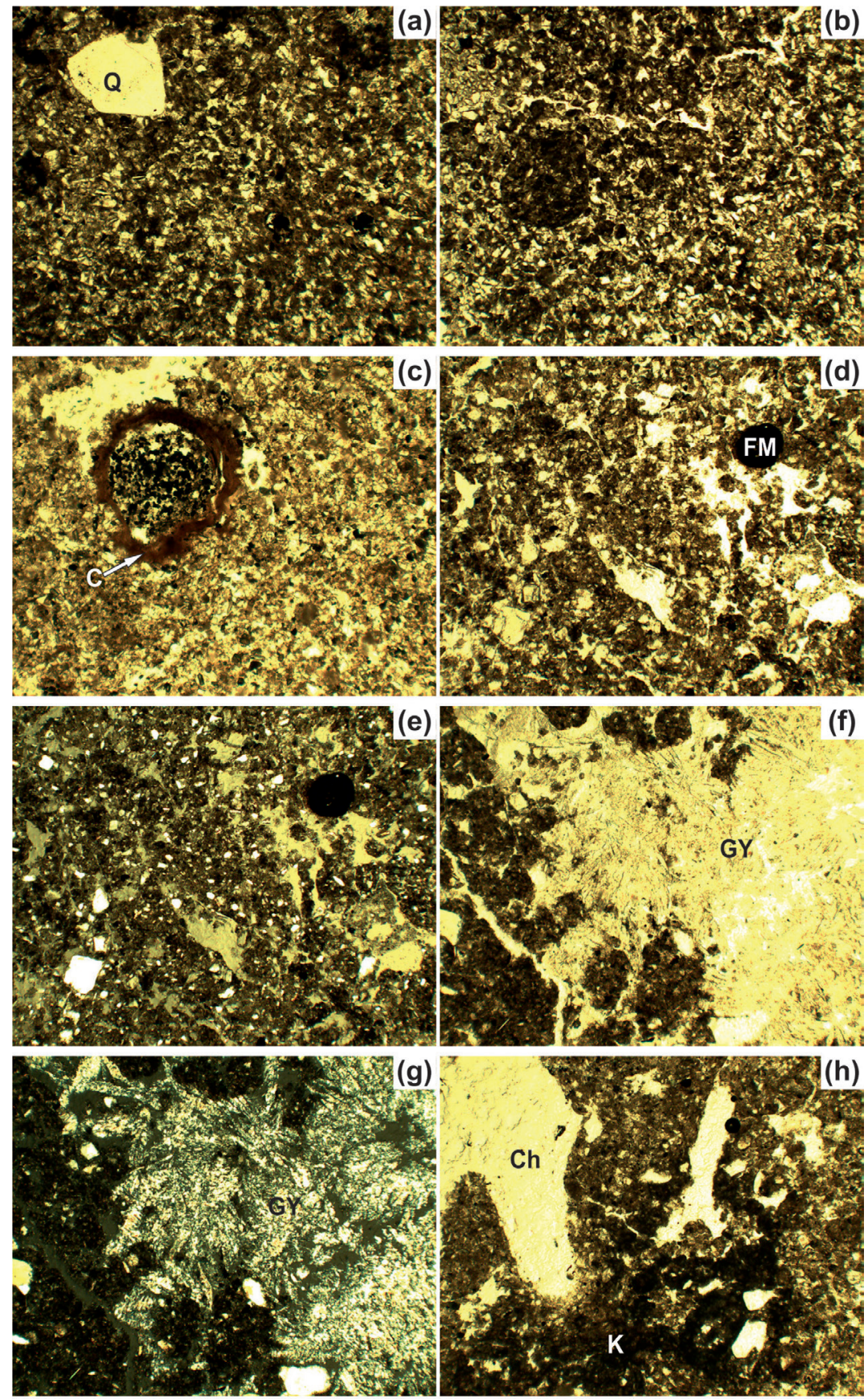

$500 \mu \mathrm{m}$

Fig. 4. Micromorphology of the Salyn interglacial paleosol: $a, b$ - the horizon AE@,

Gololobovo section (PPL); $\mathrm{c}$ - the horizon Bt, Gololobovo section (PPL); $d$ - the

horizon Ay@, Sebryakovo-Mikhailovka section (PPL); e - the same (XPL); $f$ - the horizon By, Sebryakovo-Mikhailovka section (PPL); $g$ - the same (XPL); $h$ - the horizon

By, Sebryakovo-Mikhailovka section (PPL). Symbols in the figures: Q - quartz, C coating, Ch - channel, FM - Fe-Mn pedofeatures, K - carbonate nodule, GY - gypsum pedofeatures 
The Middle Pleistocene Kamenka paleosol complex

The Middle Pleistocene Kamenka PC includes two paleosols - late Kamenka interstadial paleosol and early Kamenka interglacial one (Table 2). According to morphological descriptions, the interstadial paleosol consists of a humus horizon $0.22 \mathrm{~m}$ (Ozherelye section) to $1.10 \mathrm{~m}$ (Korostelyovo section) thick. As is seen in Fig. 5, the Kamenka PC in sections Mikhnevo (Fig. 5a) and Strelitsa-2017 (Fig. 5b) is heavily cryoturbated. Horizon A@ of the late Kamenka interstadial paleosol is present in the cryogenic wedge-like structures penetrating into the early Kamenka interglacial paleosol.

The maximum organic carbon content in the interstadial paleosol is $\mathbf{0 . 5 5 \%}$ (Korostelyovo section). The interglacial paleosol profile shows lesser proportions of organic carbon $(0.43 \%)$ as compared with the interstadial soil. In common with the interstadial paleosol, the maximum content of both is found in the Korostelyovo section.
The late Kamenka interstadial paleosols are mostly characterized by gray-brown groundmass of humus-clay composition. The paleosol described in Ozherelye section is noted for a predominance of humus-clay coatings around channels (Fig. $6 a, b)$. There is also Fe-Mn nodules present in the soil. The groundmass is penetrated by cracks, which led to the destruction of the coatings (Fig. $6 \mathrm{c}$, d). In terms of micromorphology, the humus horizon in the Sebryakovo-Mikhailovka section is characterized by brownish-gray color and aggregate structure (Fig. 6e, f). The groundmass is silty-clay. The b-fabric is striated and speckled.

The early Kamenka interglacial paleosols differ noticeably from the interstadial ones in the coating quantity and variability of their composition. In the horizon EBt dominant are laminated light brown and brown coatings, mostly clayey (Fig. 7a) in composition (Ozherelye section). There are Fe-Mn pedofeatures present here (Fig. 7b, c). In the horizon Bt the clayey coatings are confined to ancient pores (Fig. 7d). The groundmass

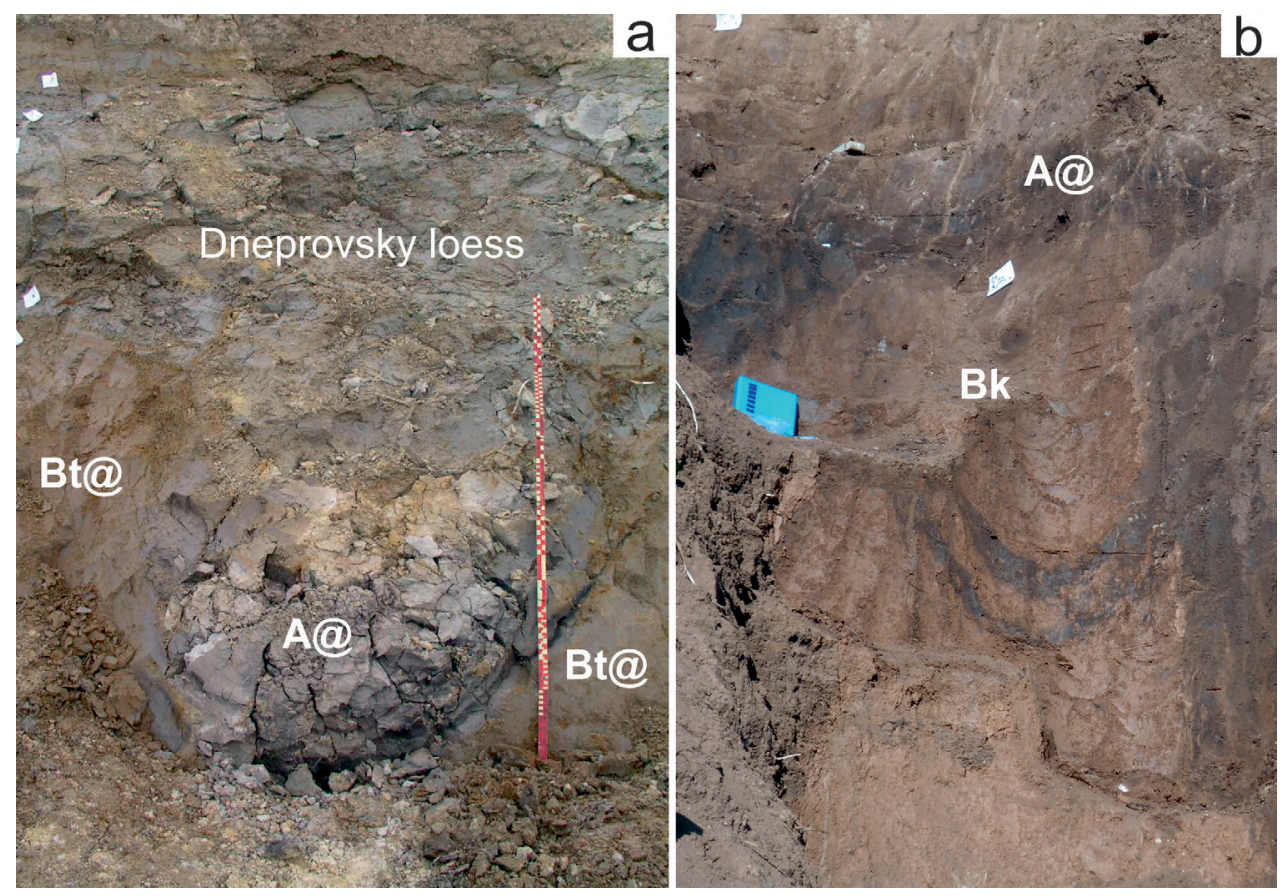

Fig. 5. Morphology of the Kamenka PC: a) Mikhnevo and b) Strelitsa-2017 sections. Symbols in the figures: horizon A@ of the interstadial paleosol, horizons Bt@ and Bk of the interglacial paleosol 

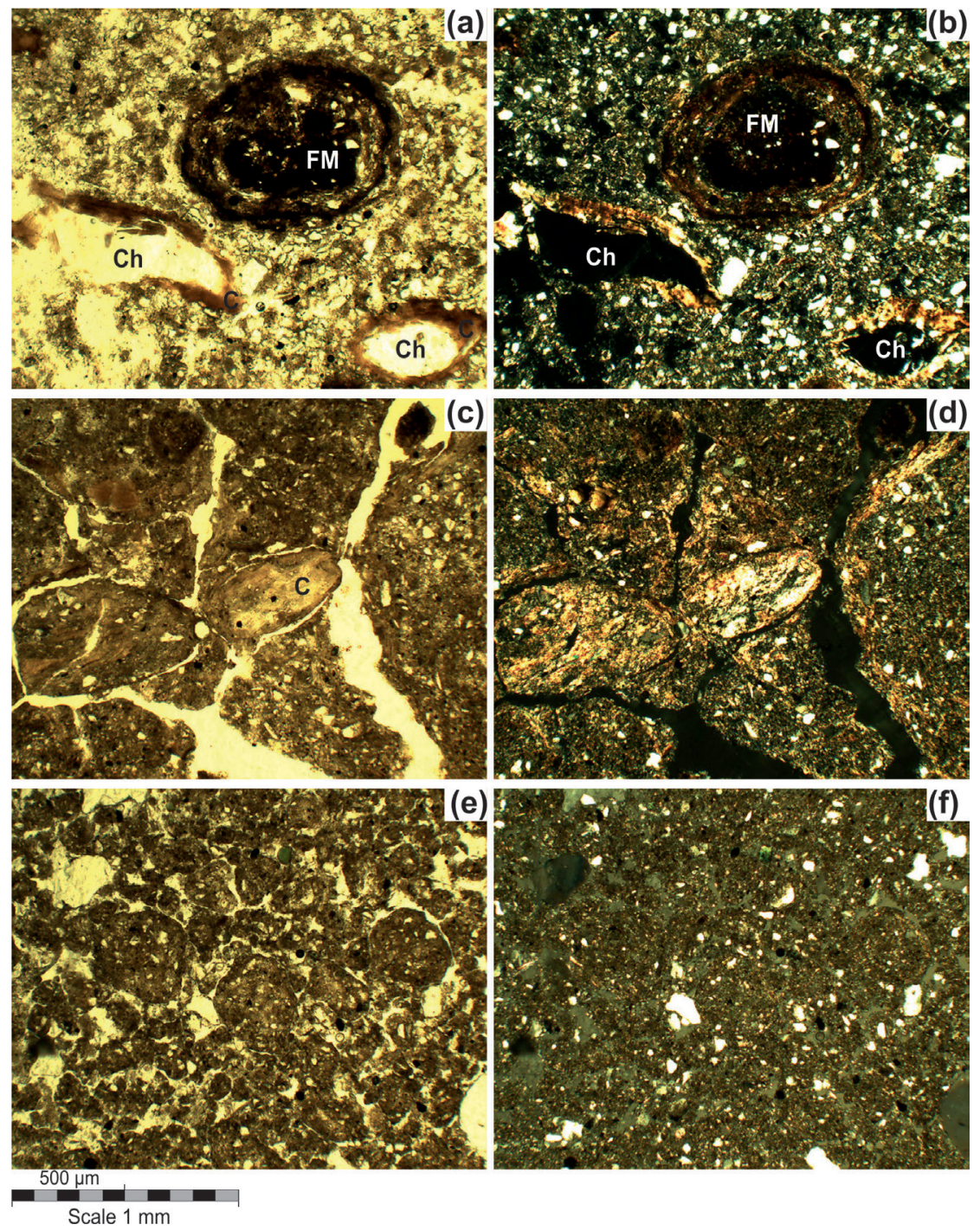

Fig. 6. Micromorphology of the Kamenka interstadial paleosol: a - the horizon A@, Ozherelye section (PPL); b - the same (XPL); c - the horizon A@, Ozherelye section (PPL); $d$ - the same (XPL); e -- the horizon A@, Sebryakovo-Mikhailovka section (PPL); $\mathrm{f}$ - the same (XPL). Symbols in the figures: $\mathrm{C}$ - coating, $\mathrm{Ch}$ - channel, FM - Fe-Mn pedofeatures

both in upper and lower parts of the interglacial soil profile is light-brown. In the Sebryakovo-Mikhailovka section the interglacial paleosol microstructure is typically well aggregated (Fig. 7e). The soil in thin section is brownish. Carbonate and Fe-Mn nodules occurs over the entire interglacial soil profile (Fig. 7f, g, h).
The Middle Pleistocene Inzhavino paleosol complex

The Inzhavino PC lies stratigraphically below Kamenka PC; in common with the latter it consists of two paleosols: the late Inzhavino interstadial paleosol and the early Inzhavino interglacial one. Cryoturbations are clearly distinguishable in the Inzhavino PC in all the sections (Gololobovo section, see Fig. 8). Interstadial pa- 

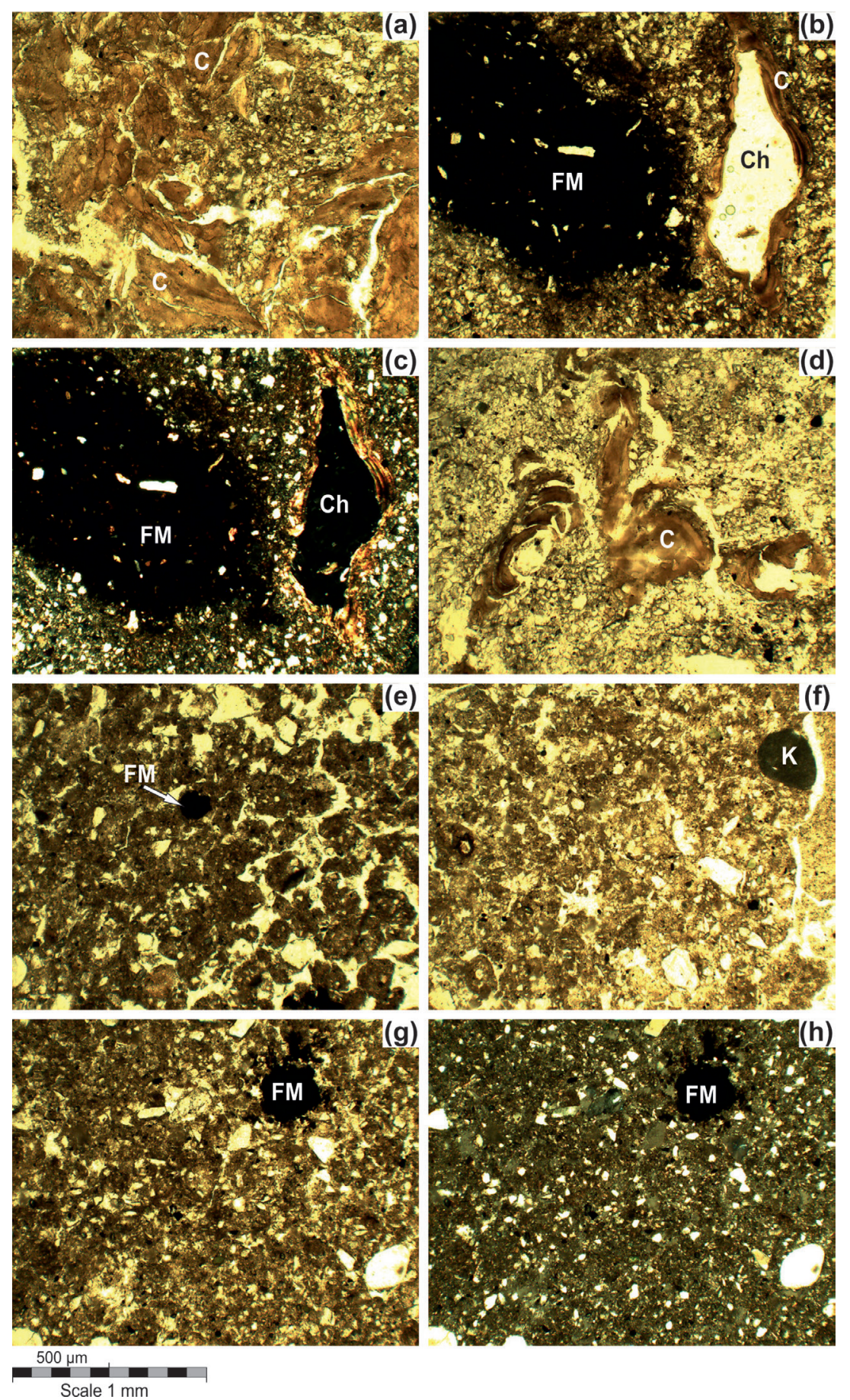

Fig. 7. Micromorphology of the Kamenka interglacial paleosol: $a, b$ - the horizon EBt, Ozherelye section (PPL); $c$ - the horizon EBt, Ozherelye section (XPL); $d$ - the horizon Bt, Ozherelye section (PPL); e, $\mathrm{f}$ - the horizon B, Sebryakovo-Mikhailovka section (PPL); $\mathrm{g}$ - the horizon BC, Sebryakovo-Mikhailovka section (PPL); $h$ - the same (XPL). Symbols in the figures: $\mathrm{C}$ - coating, $\mathrm{Ch}$ - channel, FM - Fe-Mn pedofeatures, $\mathrm{K}$ carbonate nodule 


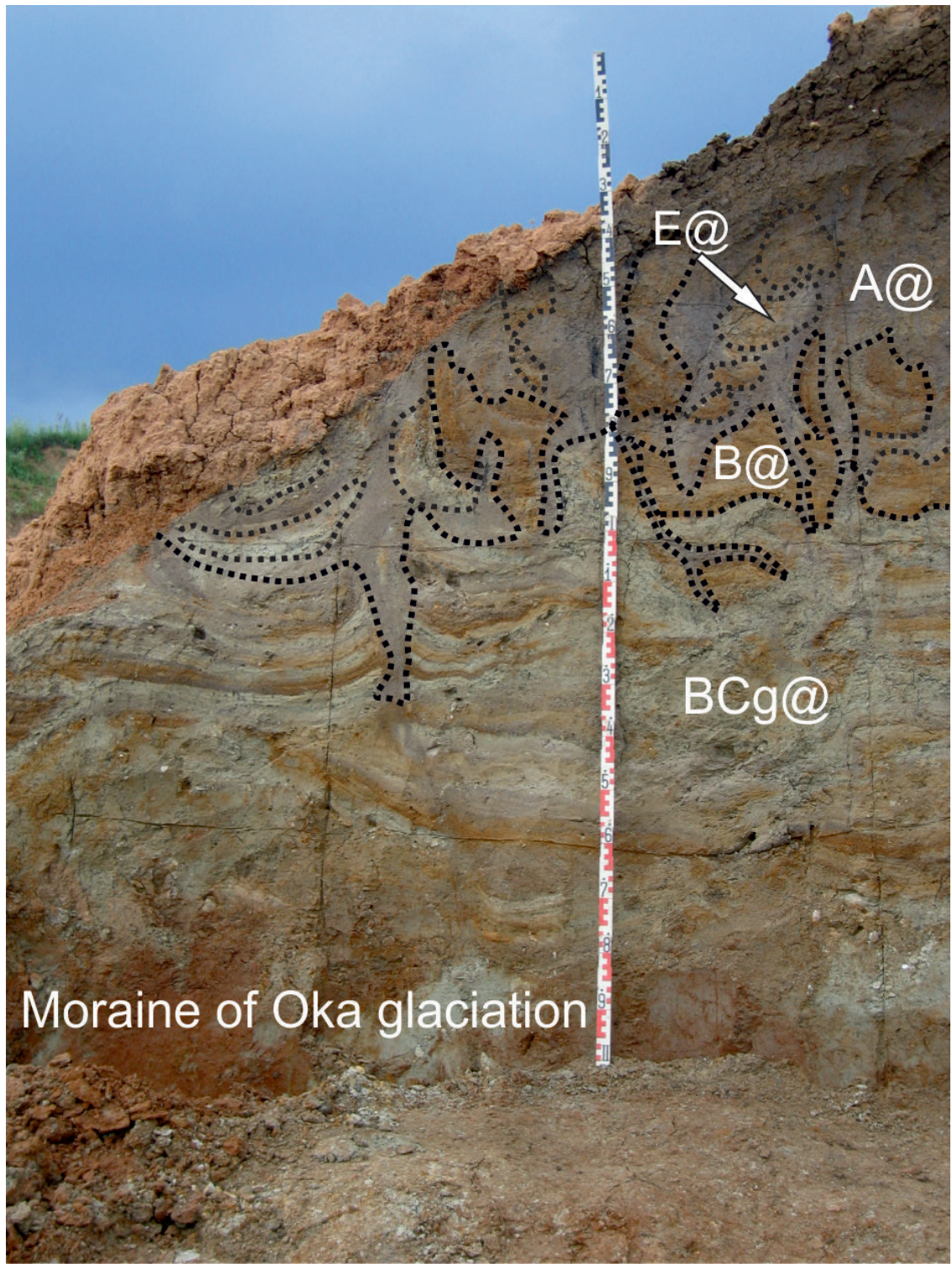

Fig. 8. Morphology of the Inzhavino PC: horizon A@ of the interstadial paleosol, horizons E@ and B@, BCg@ of the interglacial paleosol

leosols have brownish-gray humus horizon composed of clay loam. The thickness of the paleosols varies from 0.14 to 1.04 $\mathrm{m}$ (Table 2). The maximum organic carbon content in the interstadial paleosol is 0.39\% (Korostelyovo section).

The albic horizon is present in the profile of interglacial paleosols studied in sections Gololobovo, Ozherelye, Strelitsa-2017 and Likhvin. In the interglacial pa- leosols the dominant colors are dark and bright-brown argic horizons; albic horizons composed of sandy loam are whitish. In sections Korostelyovo and Sebryakovo-Mikhailovka there is no albic horizon in the soil and the profile consists of argic horizons only.

In the interglacial paleosol studied in the Gololobovo section there is a distinctly pronounced albic horizon where iron 
Table 3. Physical and chemical characteristics of the Inzhavino PC soils

\begin{tabular}{|c|c|c|c|}
\hline \multirow{2}{*}{ Genetic horizons } & \multirow{2}{*}{$\mathrm{pH}$} & \multicolumn{2}{|c|}{ Iron fractions, \% } \\
\cline { 3 - 4 } & & $\mathrm{Fe}_{\mathrm{o}}$ & $\mathrm{Fe}_{\mathrm{d}}$ \\
\hline $\mathrm{A} @$ & 8.05 & 0.18 & 0.98 \\
\hline E@ & 8.40 & 0.14 & 0.34 \\
\hline Bt1 & 8.20 & 0.21 & 0.93 \\
\hline Bt2 & 8.25 & 0.17 & 1.05 \\
\hline
\end{tabular}

content - both of oxalate extractable iron (Feo) and dithionite extractable iron (Fed) - drops noticeably (Table 3).

The microstructure of the interstadial paleosols sampled in the Gololobovo section displays granular aggregates in horizon A@ (Fig. 9a, b). Coatings of humus-clay and clay composition are recognizable in thin sections under microscope, together with $\mathrm{Fe}$ pedofeatures (Fig. 9c, d). Coatings located in pores up to $1 \mathrm{~mm}$ in diameter are composed of humus and clay particles, laminated. In the Sebryakovo-Mikhailovka section the interstadial paleosol is characterized by brown coloration in thin section, granular aggregate microstructure, silty-clayey groundmass with admixture of coarse sand (Fig. 9e, f). Packing voids are well pronounced, as well as chambers.

The interglacial paleosol exposed in the Gololobovo section (horizon E) contains large Fe-Mn nodules (Fig. 10a, b), though no coatings. Lower in the profile, in horizon Bt, coatings, mostly clayey, appear and increase in number downwards (Fig. 10c, d). The b-fabric is speckled. The groundmass of the interglacial paleosol shows a silty-clay composition in the Sebryakovo-Mikhailovka section (Fig. 10e, f). There are also large (more than $1 \mathrm{~mm}$ in diameter) carbonate concretions and Fe-Mn nodules (Fig. 10g, h).

\section{DISCUSSION}

Synthesis of paleoenvironmental data obtained as a result of integrated studies of the loess-soil sequences in the central East European Plain made possible to trace the principal stages in the soil evolution in the region over $\sim 400000$ years, that is, since the Middle Pleistocene to the present days. Table 4 summarizes the results of the micromorphological studies of the Loess-Paleosol Sequences. A relative abundance (Stoops 2003) of Fe-Mn, carbonate, and gypsum pedofeatures, as well as coatings is given.

According to Urusevskaya (2011), the main processes in the Albic Retisols (latitudinal zone I) are lessivage, humus accumulation and mineral acid hydrolysis. The leading soil-forming processes in the Greyzemic Phaeozems (latitudinal zone II) are ground leaf litter formation, humus accumulation, acid hydrolysis of minerals and lessivage. The microstructure of both Greyzemic Phaeozems and Albic Retisols are distinguished by an abundance of Fe and $\mathrm{Mn}$ pedofeatures (Table 3), indicative of wetting (Gerasimova et al. 1992; Zaidel'man and Nikiforova 2010; Lindbo et al. 2010). In the Chernozems (III latitudinal zone) development the leading processes were as follows: ground leaf litter formation, humus accumulation, active structuring due to biogenic processes and flocculation, and carbonate redistribution due to eluvial and illuvial processes (Chernova 2011). The microstructure of Chernozems is noted, besides Fe-Mn pedofeatures, for carbonate nodules present in abundance.

\section{The Late Pleistocene Mezin paleosol complex}

The presence of humus-clayey coatings, together with a relatively high humus content in the Krutitsa interstadial paleosol (exposed in Suvorotino, Bogolyubovo, Gololobovo, Mikhnevo, Ozherelye, Likhvin, Bryansk, Arapovichi sections), suggests a 

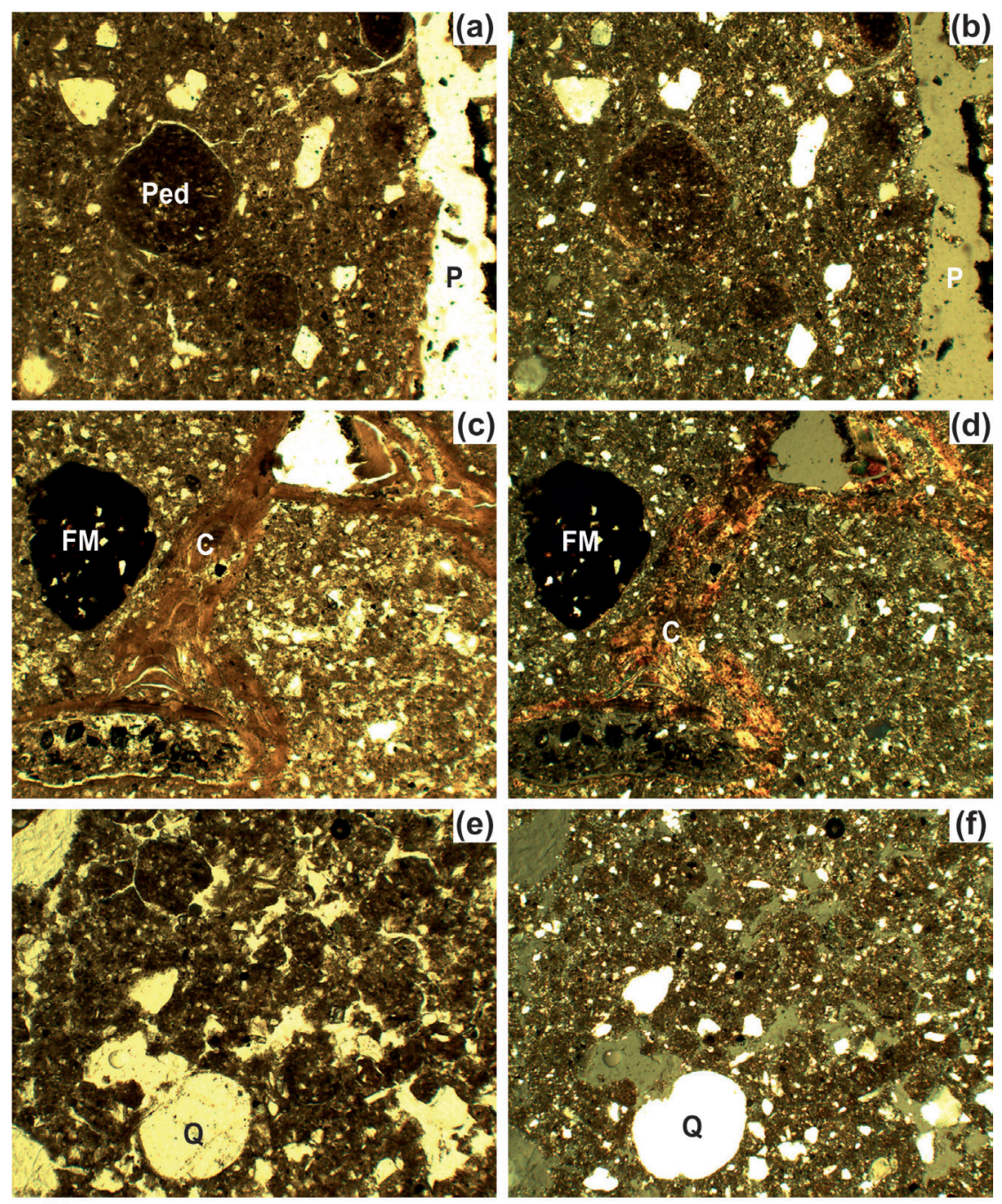

$500 \mu \mathrm{m}$

Scale $1 \mathrm{~mm}$

Fig. 9. Micromorphology of the Inzhavino interstadial paleosol: a - the horizon A@, Gololobovo section (PPL); b - the same (XPL); c - the horizon A@, Gololobovo section $(P P L) ; d$ - the same (XPL); e - the horizon A@, Sebryakovo-Mikhailovka section (XPL); $f$ - the same (XPL). Symbols in the figures: Ped - soil aggregate, $C$ - coating, $P$ - plane, FM - Fe-Mn pedofeatures, $\mathrm{Q}$ - quartz

leading role of humus accumulation processes. Large granular aggregates and were formed in the paleosols as a result of cryogenic processes (Van Vliet-Lanoë 1998; Van Vliet-Lanoë 2010; Todisco and Bhiry 2008; Villagran et al. 2013), in the Russian literature, these aggregates are called «ooid aggregates» (Morozova 1965; Gerasimova et al. 1992). The influence of cryogenic processes on the soil profile is also well expressed at the macro level. In the morpho- logical description, large permafrost wedges are distinguished in the soil profile, as for example in horizons A@ Kamenka (Fig. 5) or Inzhavino (Fig. 8) PC. Taking into consideration the small thickness of their profile (0.42 m), the listed characteristics suggest a certain similarity of those paleosols to modern imperfectly developed Gleyic Chernozems (Panin 2007; Panin 2015; Velichko and Morozova 2015) formed under steppe vegetation (Novenko et al. 2008). In 

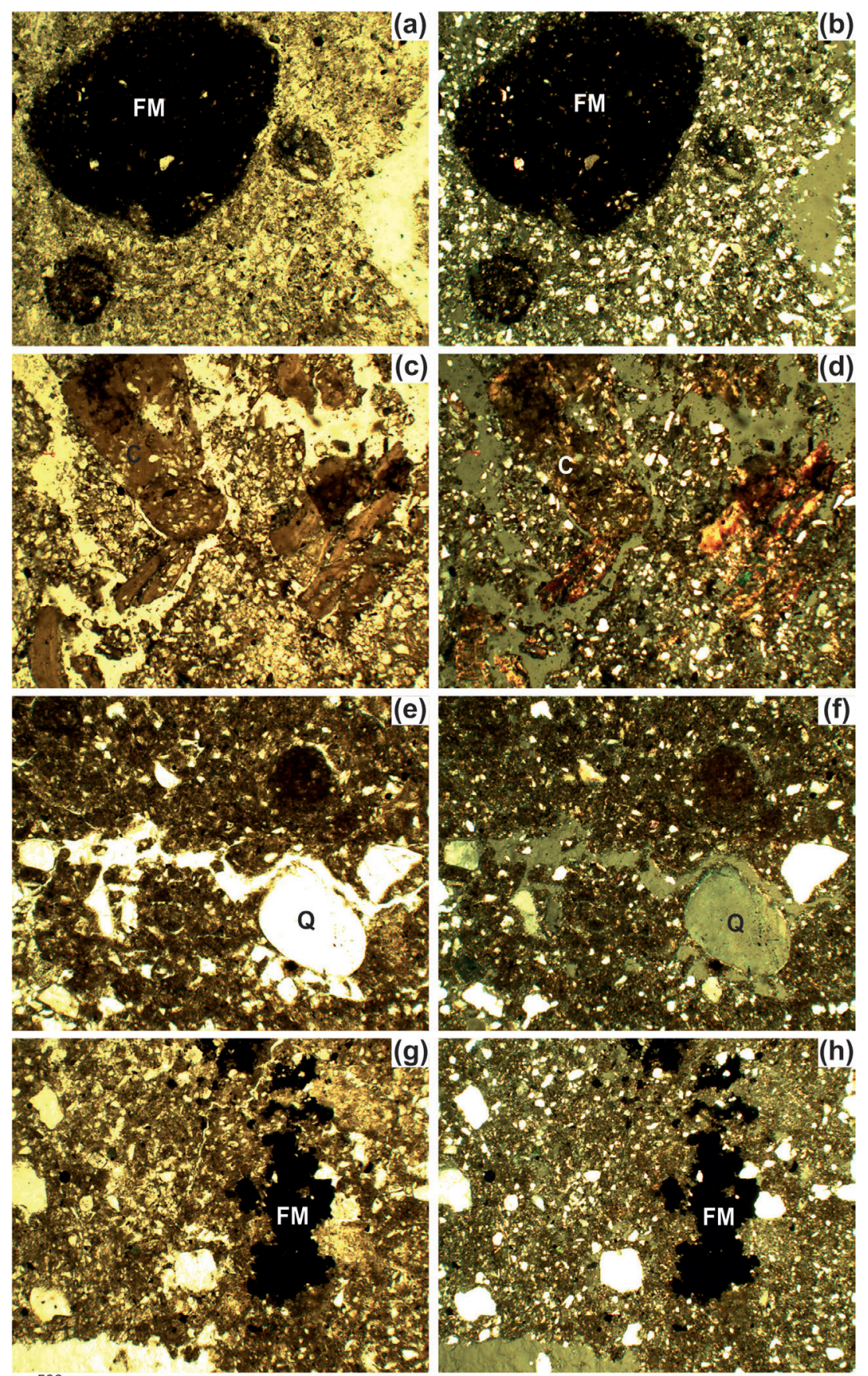

$500 \mu \mathrm{m}$

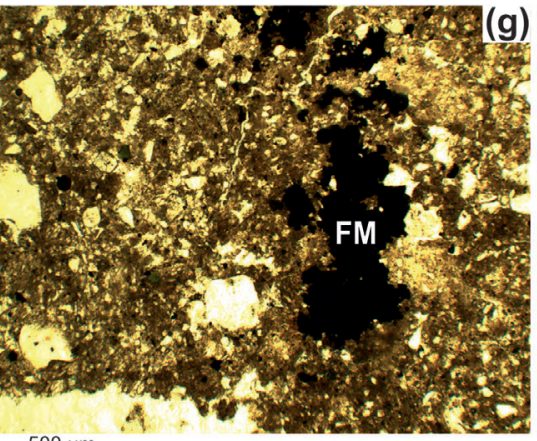

Fig.10. Micromorphology of the Inzhavino interglacial paleosol: a - the horizon E@, Gololobovo section (PPL); b - the same (XPL); c - the horizon Bt, Gololobovo section (PPL); $d$ - the same (XPL); e - the horizon Bk, Sebryakovo-Mikhailovka section (PPL); $f$ - the same (XPL); $g$ - the horizon Bk, Sebryakovo-Mikhailovka section (PPL); $h$ - the same (XPL). Symbols in the figures: $F M-F e-M n$ pedofeatures, $C$ - coating, $Q$ - quartz 
Table 4. Comparison between characteristics of the surface soil and paleosols microstructure $(-=$ absent; $+=$ very few,$++=$ common,$+++=$ frequent, $++++=$ dominant)

\begin{tabular}{|c|c|c|c|c|c|}
\hline \multirow{2}{*}{$\begin{array}{l}\text { Latitudinal } \\
\text { zone } \\
\text { (see Fig. 11) }\end{array}$} & \multirow[b]{2}{*}{ Names of sections } & \multicolumn{4}{|c|}{ Pedofeatures } \\
\hline & & $\begin{array}{c}\text { Fe and } \\
M n\end{array}$ & $\begin{array}{c}\text { Clay } \\
\text { coating }\end{array}$ & Carbonate & Gypsum \\
\hline \multicolumn{6}{|c|}{ Surface soil (Holocene) (Fig. 11A) } \\
\hline $\begin{array}{c}\text { I } \\
\text { (Albic Retisols) }\end{array}$ & - & +++ & +++ & - & - \\
\hline $\begin{array}{c}\text { ॥ } \\
\text { (Greyzemic } \\
\text { Phaeozems) }\end{array}$ & $\begin{array}{c}\text { Suvorotino, Bogolyubovo, } \\
\text { Gololobovo, Mikhnevo, } \\
\text { Ozherelye, Likhvin, Bryansk, } \\
\text { Arapovichi }\end{array}$ & +++ & ++++ & - & - \\
\hline $\begin{array}{c}\text { III } \\
\text { (Chernozems) }\end{array}$ & $\begin{array}{c}\text { Korostelyovo, Sebryakovo- } \\
\text { Mikhailovka, Strelitsa-2017, } \\
\text { Gun'ki }\end{array}$ & + & - & +++ & - \\
\hline \multicolumn{6}{|c|}{ Salyn interglacial paleosol (Fig. 11B) } \\
\hline $\begin{array}{c}\text { I } \\
\text { (Albic Retisols) }\end{array}$ & Suvorotino, Bogolyubovo & ++++ & ++ & - & - \\
\hline $\begin{array}{l}\text { ॥ } \\
\text { (Greyzemic } \\
\text { Phaeozems } \\
\text { and Retisols) }\end{array}$ & $\begin{array}{c}\text { Gololobovo, Mikhnevo, } \\
\text { Ozherelye, Likhvin, Bryansk, } \\
\text { Arapovichi }\end{array}$ & ++ & +++ & + & - \\
\hline $\begin{array}{c}\text { III } \\
\text { (Gypsic } \\
\text { Chernozems } \\
\text { or Gypsic } \\
\text { Kastanozems) }\end{array}$ & $\begin{array}{c}\text { Korostelyovo, Sebryakovo- } \\
\text { Mikhailovka, Strelitsa-2017, } \\
\text { Gun'ki }\end{array}$ & + & + & +++ & ++++ \\
\hline \multicolumn{6}{|c|}{ Early Kamenka interglacial paleosol (Fig. 11C) } \\
\hline $\begin{array}{c}\text { I } \\
\text { (Cambisols) }\end{array}$ & $\begin{array}{c}\text { Suvorotino, Bogolyubovo, } \\
\text { Gololobovo, Mikhnevo, } \\
\text { Ozherelye, Likhvin, Bryansk, } \\
\text { Arapovichi, Strelitsa-2017, } \\
\text { Gun'ki }\end{array}$ & +++ & ++++ & - & - \\
\hline $\begin{array}{c}\| \\
\text { (Chernozems) }\end{array}$ & $\begin{array}{c}\text { Korostelyovo, Sebryakovo- } \\
\text { Mikhailovka }\end{array}$ & ++ & - & +++ & - \\
\hline \multicolumn{6}{|c|}{ Early Inzhavino interglacial paleosol (Fig. 11D) } \\
\hline $\begin{array}{l}\text { I } \\
\text { (Albic Retisols } \\
\text { and Greyzemic } \\
\text { Phaeozems) }\end{array}$ & $\begin{array}{l}\text { Gololobovo, Mikhnevo, } \\
\text { Ozherelye, Likhvin, Bryansk, } \\
\text { Arapovichi, Strelitsa-2017 }\end{array}$ & ++++ & ++++ & - & - \\
\hline $\begin{array}{c}\| \\
\text { (Chernozems) }\end{array}$ & $\begin{array}{l}\text { Korostelyovo, Sebryakovo- } \\
\text { Mikhailovka, Gun'ki }\end{array}$ & +++ & - & ++ & - \\
\hline
\end{tabular}


sections Korostelyovo, Sebryakovo-Mikhailovka, Gun'ki and Strelitsa-2017 the microstructure of interstadial paleosols is distinct for large regularly shaped gypsum crystals; according to Gerasimova et al. (1992), such crystals may develop under conditions of continuous, or long-term, presence of water in the soil, which makes possible the crystal growth. Most likely gypsum was introduced by eolian processes and formed crystals of rhomboid forms in the process of soil-formation. The considered soils may be classified with Gypsic Chernozems.

In the Salyn paleosol microstructure there is a clearly traceable albic horizon that contains Fe-Mn nodules, clayey coatings are present in the argic horizon (Suvorotino, Bogolyubovo sections). The described characteristics permit the soil to be classified as texture-differentiated soils. In the Gololobovo, Ozherelye, Likhvin, Bryansk, Arapovichi sections Fe-Mn nodules become less pronounced in the Salyn paleosol microstructure, while the coatings gain in abundance. There are clayey coatings of illuviation, undoubtedly indicative of lessivage (transportation of clay matter). According to Novenko et al. (2008), at the beginning of the Mikulino Interglacial the studied region was dominated by spruce communities, pine and birch-pine forests; later on, oak forests appeared with elm, ash, and maple. As suggested by the pollen analysis data, that time was marked by an increase in moisture supply and the stagnant water persisting on the land surface. The considered Salyn paleosol described in Suvorotino and Bogolyubovo sections may be classified as Albic Retisols, in the GoIolobovo, Ozherelye, Likhvin, Bryansk, Arapovichi sections the paleosol is assigned to Greyzemic Phaeozems. The results obtained are in a good agreement with conclusions by Sycheva (1998) on Retisols being also formed near the Aleksandrovsky Quarry $\left(51^{\circ} 36^{\prime} 09^{\prime \prime} \mathrm{N}, 36^{\circ} 06^{\prime} 51^{\prime \prime} \mathrm{E}\right)$ in the Interglacial.

In Sebryakovo-Mikhailovka, Korostelyovo, and Gun'ki sections the Salyn soil micromorphology studies revealed the presence of large rhomb-shaped pedofeatures of gypsum and carbonates. Similar forms of gyp- sum were described in the Salyn paleosol in the Azov Sea region (Velichko et al. 2017a; Velichko et al. 2017b; Panin et al. 2018); that gives ground for suggestion on a similarity in the soil-forming processes all over the south of the East European Plain. Gypsum is present in the soil as a concentration of small and larger crystals. Presumably, it could be related to fluctuations of the humidity, when the soil profile was repeatedly dried up (Minashina and Shishov 2002; Poch et al. 2010). As compared with northern regions, the soil profile is richer in organic carbon (0.49\%), its thickness is $1.32 \mathrm{~m}$. Taking into consideration the presence of gypsum and carbonates in the soil and well aggregated groundmass, one may suggest that the paleosol development followed the Chernozem type. The considered soils may be compared, therefore, with modern Gypsic Chernozems or Gypsic Kastanozems. According to Glushankova (2012), soils at the Korostelyovo section vicinities at the Mikulino Interglacial were represented by a combination of forest and meadow-chernozem soils.

\section{The Middle Pleistocene Kamenka paleosol complex}

The interstadial paleosol known as late Kamenka has much in common in its genesis with the Krutitsa interstadial paleosol. In the northern sections (Gololobovo, Ozherelye, Mikhnevo) studies of the soil microstructure revealed humus-clayey coatings, along with Fe nodules and carbonate pedofeatures. There are traces of cryoturbations recognizable in the paleosol profile. It may be concluded that the Kamenka interstadial paleosols are practically identical to those of Krutitsa in their characteristic. In the Gololobovo, Mikhnevo, Ozherelye sections in the studied region the paleosols are comparable with imperfectly developed modern Gleyic Phaeozems (Panin 2007, 2015; Velichko and Morozova 2015). Paleosols of the Korostelyovo, Sebryakovo-Mikhailovka, Strelitsa-2017 and Gun'ki sections are attributed to imperfectly developed Kastanozems and Haplic Kastanozems, or to imperfectly developed Haplic Chernozems.

Studied in sections Gololobovo, Ozherelye, Mikhnevo, and Likhvin, the Kamenka inter- 
glacial is typically noted for a thick profile (1.33 m, on average) and bright brown color. The interglacial soil profile consists primarily 으 of horizons AB, EBt and Bt. The microstructure displays Fe-Mn pedofeatures and Fe nodules indicative of abundant wetting of the upper horizons. The whitish albic horizon does not stand out morphologically; at the level of microstructure the groundmass is brown or light brown in color. It may be attributed to the presence of clayey coatings; the latter filling completely pores and preventing iron compounds from penetrating deeper, so that the albic horizon turns brown due to the iron presence (Bronnikova and Targulyan 2005). The main soil-forming processes that took part in the paleosol profile development are lessivage, clayization, humus accumulation and illuviation. As follows from the micro-biomorphic analysis, the early Kamenka interglacial paleosol developed under broadleaf forests. Those paleosols may be classified as Cambisols, developed under broadleaf forests (Glushankova and Agadjanian 2015). The modern analogs of those soils are found in Central Europe, in particular, in the Vistula River basin (Świtoniak and Charzyński 2014).

In the Sebryakovo-Mikhailovka and Korostelyovo sections, the early Kamenka interglacial paleosol is aggregated in microstructure; there are pedofeatures of carbonates and Fe nodules, indicative of warm and wet climate at the time of soil development (Kovda et al. 2016). The groundmass is well aggregated, with granular structure, the soil profile thickness is 1.08 on average, organic carbon content is $0.25 \%$. Based on those characteristics, the soil may be placed in the group of Chernozems.

\section{The Middle Pleistocene Inzhavino paleosol complex}

The microstructure studies performed on the late Inzhavino interstadial paleosol exposed in Gololobovo and Ozherelye sections revealed the dominance of humus-clayey coatings, and the presence of Fe nodules. The entire paleosol profile is $0.36 \mathrm{~m}$ thick on the average, organic carbon content amounts to $0.17 \%$. The main soil-forming processes that account for the soil appear- ance are humus accumulation, lessivage, and surficial gleying. Hence the interstadial paleosols may be classified as Gleyic Phaeozems. There are morphologically distinct humus horizons in the interstadial paleosols of the Korostelyovo and Sebryakovo-Mikhailovka sections bearing recognizable traces of cryogenic processes. Granular aggregates are seen in their microstructure, along with carbonate pedofeatures. The average thickness of the paleosol profiles amounts to $0.99 \mathrm{~m}$, organic carbon content is $0.39 \%$. Unlike interstadial paleosols of the Mezin and Kamenka PC, gypsum pedofeatures are practically absent from the paleosol, which suggests a wetter climate than that of the subsequent interstadials. Calcic Chernozems developed under meadow steppe now may be taken as modern analogs of that paleosol.

The early Inzhavino paleosol is dated to the Likhvin Interglacial. Its profile is $1.5 \mathrm{~m}$ thick on the average, organic carbon is $0.17 \%$. A whitish albic horizon is clearly seen in the soil profile. In common with other interglacial paleosols, there are numerous coatings (clayey and silty-clayey ones) in the Inzhavino paleosol microstructure. Our data gave grounds to assign the soil to texture-differentiated group, under coniferous-broadleaf forests (Glushankova and Agadjanian 2015). Among the modern soils Albic Retisols in combination with Greyzemic Phaeozems may be considered as their analogs.

In the Korostelyovo and Sebryakovo-Mikhailovka sections the early Inzhavino soil profile is, on average, $0.66 \mathrm{~m}$ thick, organic carbon content is $0.21 \%$. The microstructure features carbonates, the groundmass is well aggregated, silty-clayey in composition, contains Fe-Mn nodules. The Likhvin interglacial paleosols in the region may be classed with Chernozem ones. The present-day analogs of the paleosols are Chernozems under meadow steppe (Glushankova and Agadjanian 2015).

The studies performed on the paleosol series revealed the latitudinal zone typical of the regional soils during that interval: chernozemic soils of the southern arid regions changed northward into humid texturally-differentiated soils. In the interglacial pe- 
riods the soil zonation resembled closely the modern latitudinal zone. At interstadials, poorly developed Chernozems were most widespread under meadow-steppe vegetation. Fig. 11 shows the geographic distribution of present-day soils of the central East European Plain and reconstructed paleosols attributed to the Mikulino, Kamenka, and Likhvin interglacials. In addition, some data used in the reconstructions were taken from published materials on LPS studied in the sections: Aleksandrovsky Quarry (Sycheva 1998; Sycheva and Sedov 2012; Sycheva et al. 2017), Mikhailovka (Agadjanian and Glushankova 2017), Afonino (Dlussky 2007), Likhvin (Lazukov and Chebotareva 1977), as
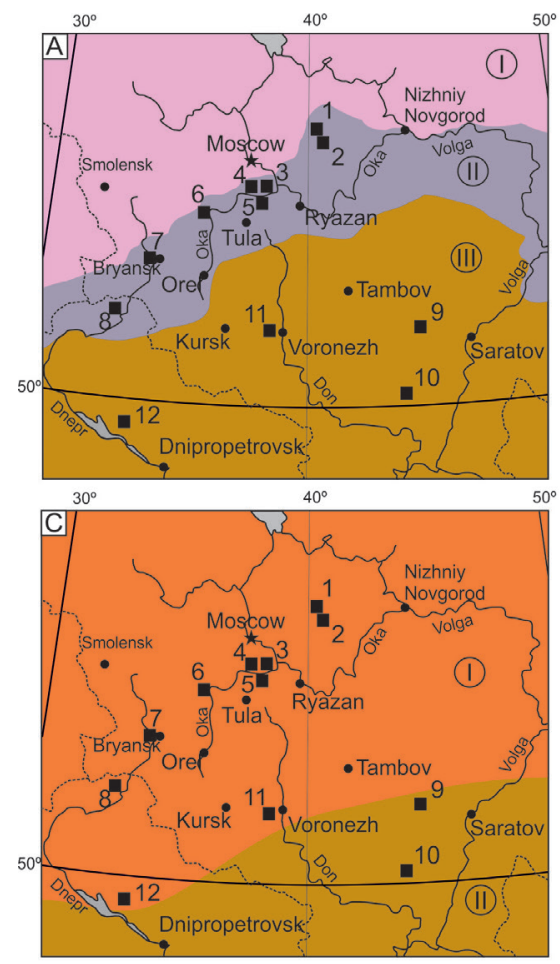

well as sections published by Dlussky (2001), Markov (1977), Yakimenko (1995), Dodonov and Velichko (2003), Glushankova (2008, 2012), Glushankova and Agadjanian (2015), Bolikhovskaya and Molodkov (2006), Virina et al. (2000), a.o.

As can be seen from Table 4, the quantity of Fe-Mn pedofeatures and coatings decreases from north to south, while the quantity of carbonates increases to the south. First of all, this could be due to a change in the amount of precipitation. So for surface soils of I and II (Fig. 11) zones, the average annual precipitation is $540-650 \mathrm{~mm}$, and for III zone is 300 - $560 \mathrm{~mm}$ per year. The same
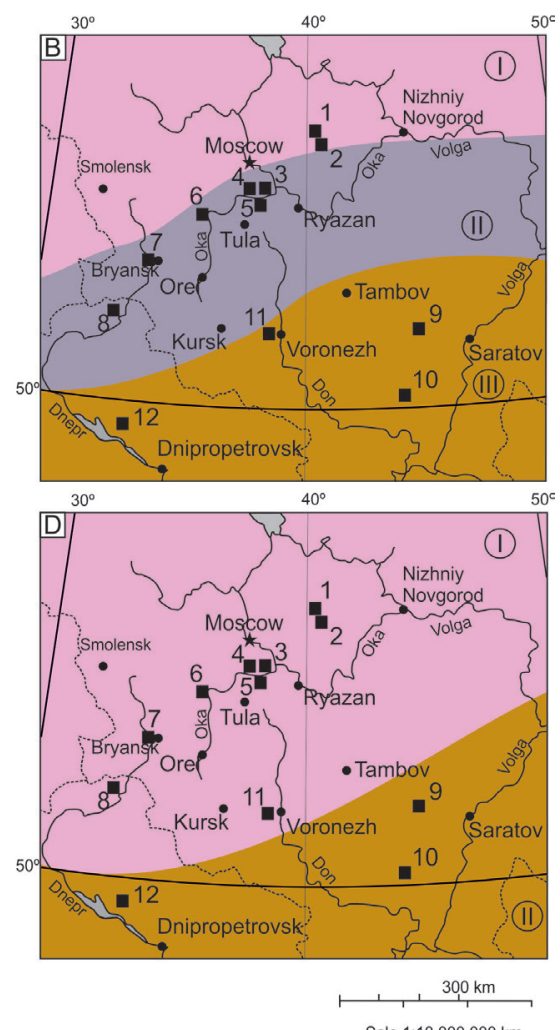

Sale $1: 18000000 \mathrm{~km}$

Fig. 11. Reconstructions of the geographic distribution of the paleosols of the interglacials and the surface soils (numbers on the maps correspond to those in Fig. 1):

A - surface soils (Urusevskaya et al. 2011): I - Albic Retisols zone; II - Greyzemic Phaeozems zone in combination with Retisols; III - Chernozems zone;

B - reconstructed paleosols of the Mikulino interglacial: I - Albic Retisols zone; II Greyzemic Phaeozems zone in combination with Albic Retisols; III - Gypsic Chernozems or Gypsic Kastanozems zone;

C - paleosols of the Kamenka Interglacial: I - Cambisols zone; II - Chernozems zone; D - paleosols of the Likhvin interglacial: I - Albic Retisols and Greyzemic Phaeozems zone; 
trend is typical for the Salyn paleosol (MIS $5 e)$, where in more southern sections, in addition to carbonates, gypsum appears. According to Velichko et al. (2004) during the Mikulino interglacial the paleosols of the I and II zones (Table 4, Fig. 11) developed at an average annual precipitation of 600 - $650 \mathrm{~mm}$ per year, while the paleosols of the III zone (Table 4, Fig. 11) developed at $580 \mathrm{~mm}$ per year (Ryskov et al., 2008). The average annual precipitation in Kamenka (MIS 7 (9) and Likhvin (MIS 9 (11)) interglacials varies between 600 and $750 \mathrm{~mm}$, but the greatest amount of precipitation is typical for the Likhvin interglacial (Velichko et al., 2004; Ryskov et al., 2008). As can be seen from Table 4, the maximum content of Fe$\mathrm{Mn}$ pedofeatures and coatings is limited to the Inzhavino paleosol of the Likhvin interglacial, which confirms the degree of moistening of the paleosols of this period. Therefore, according to the microfabric of paleosols, it can be seen that in the territory of the center of the East European Plain the most humid conditions are characteristic for the Likhvin interglacial (MIS 9 (11)) with their gradual decrease towards the Holocene period.

According to Velichko et al. (2004) during the interstadial periods of the Late and Middle Pleistocene the amount of precipitation was 220 - $450 \mathrm{~mm}$ per year. In the microfabric of interstadial paleosols, there are Fe-Mn pedofeatures and coatings, and in more southern sections carbonate and gypsum nodules, but their quantity does not change significantly during the considered Pleistocene periods, which suggests similar pedogenic conditions for their formation. In the interstadials periods, considered soil complexes, the climate did not vary greatly from the Middle to Late Pleistocene, but the soil cover during these periods had latitudinal zonality, which consisted of two zones.

\section{CONCLUSION}

1. As follows from the data on micromorphology, the interstadial and interglacial paleosols permit tracing the changes in climate of the time intervals when the paleosols developed in the center of the East European Plain. The soil microstructure dominated by Fe-Mn nodules and coatings is typical of the soil formation in humid climate, while the presence of carbonate pedofeatures and gypsum suggests the climate aridity.

2. In the northern part of the East European Plain interglacial paleosols of the Mikulino and Inzhavino age had a texture-differentiated profile, while paleosols dated to the Kamenka interglacial lacked of albic horizon. In the southern regions the profile of the interglacial paleosols feature blackish chernic surface horizon and with secondary carbonates.

3. During interstadials of the Late and Middle Pleistocene the latitudinal zonality was fairly well pronounced, two zones being distinguished within the considered region. Interglacial paleosols - Mikulino permitted to identify three latitudinal zones, the Kamenka and Inzhavino interglacial soils were also distributed over two latitudinal zones.

\section{ACKNOWLEDGEMENTS}

The study was funded in part by Russian Foundation for Basic Research to the research projects № 18-04-00145, 17-5553035. Micromorphological studies of the Sebryakovo-Mikhailovka section were carried out in the framework of the State Task № 0148-2019-0005 (Registration Number 01201352491).

The author is thankful to Spasskaya I.I. for her help in language editing. The authors would like to thank the anonymous reviewers for their helpful suggestions. 


\section{REFERENCES}

Agadjanian A.K. and Glushankova N.I. (2017). Quaternary stratigraphy and developmental history of the central Russian periglacial-loessal province. Stratigraphy and Geological Correlation, 25(4), pp. 445-462.

Bolikhovskaya N.S. and Molodkov A.N. (2006). East European loess-palaeosol sequences: Palynology, stratigraphy and correlation. Quaternary International, 149, pp. 24-36. doi: https://doi.org/10.1016/j.quaint.2005.11.015.

Bolikhovskaya N.S. (1995). The evolution of the loess-paleosol formation of the Northern Eurasia. Moscow: Moscow State University press. (in Russian).

Bronger A. and Heinkele T.H. (1989). Micromorphology and genesis of paleosols in the Luochuan Loess Section, China: pedostratigraphic and environmental implications. Geoderma, 45, pp. 123-143. doi: https://doi.org/10.1016/0016-7061(89)90046-3

Bronger A., Winter R. and Heinkele T. (1998). Pleistocene climatic history of East and Central Asia based on paleopedological indicators in loess-paleosol sequences. Catena, 34, pp. 1-17. doi: https://doi.org/10.1016/S0341-8162(98)00078-2

Bronnikova M.A. and Targulian V.O. (2005). Assemblage of cutans in texturally differentiated soils (case study for Albeluvisoils of the EastEuropean Plain). Moscow:PBMC «Akademkniga». (in Russian)

Chernova O.V. (2011). Vorony - Calcic CHERNOZEMS. In: Shoba S.A. (Ed.). National Soil Atlas of Russia. Moscow. Astrel. pp. 136-137. (in Russian)

Chizhikova N.P., Morozova T.D. and Panin P.G. (2007). Mineralogical composition of the clay fraction and micromorphology of the Middle and Late Pleistocene paleosols and loesses of the center part of the East European plain. Eurasian Soil Science, 40(12), pp. 1343-1354.

Costantini EAC. (2017). Paleosols and pedostratigraphy. Applied Soil Ecology, 123, pp. 597600. doi: https://doi.org/10.1016/j.apsoil.2017.09.021

Urusevskaya I.S. (2011). Umbric ALBELUVISOLS. In: Shoba S.A. (Ed.). National Soil Atlas of Russia. Moscow. Astrel. pp. 106-107. (in Russian)

Urusevskaya I.S., Martynenko I.A. and Alyabina I.O. (2011). Soil map. In: Shoba S.A. (Ed.). National Soil Atlas of Russia. Moscow. Astrel. pp. 72-73. (in Russian)

Dlussky K.G. (2001). Middle Pleistocene soil formation of the center of the East European Plain. M.: Ph.D. Thesis in Geography. Moscow: Institute of Geography, Russian Academy of Science/ (in Russian)

Dlussky K.G. (2007). Likhvin interglacial polygenetic paleosol: A reconstruction on the Russian Plain. Quaternary International, 162-163, pp. 141-157.doi: https://doi.org/10.1016/j. quaint.2006.10.029

Dodonov A.E. and Velichko A.A. (Eds.). (2003). Loess and Paleoenvironment. Abstracts and Field Excursion Guidebook. Moscow: GEOS. (in Russian)

FAO. (2006). Guidelines for Soil Description. fourth ed. Rome. 
Fedoroff N., Courty M.-A. and Guo Z. (2010). Palaeosoils and Relict Soils. In: Stoops G., Marcelino V., Mees F., editors. Interpretation of micromorphological features of soils and regoliths. pp. 623-662.

Gerasimova M.I., Gubin S.V. and Shoba S.A. (1992). Micromorphological features of the USSR zonal soils. Information and reference materials. Pushchino. (in Russian)

Gerasimova M.I., Kovda I.V., Lebedeva M.P. and Tursina T.V. (2011). Micromorphological terms: The state of the art in soil microfabric research. Eurasian Soil Science 44(7), pp. 739752.

Glushankova N.I. and Agadjanian A.K. (2015). Reconstruction of paleogeographic events in Pleistocene history of Don, Volga and Kama basins. Proceedings of the Russian Geographical Society 47(2), pp. 38-56. (in Russian with English abstract and references)

Glushankova N.I. (2008). Paleopedogenesis and past environments of Eastern Europe during the Pleistocene. Moscow-Smolensk. (in Russian)

Glushankova N.I. (2012). Structure, composition, and depositional environments of recent sediments in the Upper Don River basin inferred from the Korostelevo section. Lithology and Mineral Resources, 47(3), pp. 204-216.

Haase D., Fink J., Haase G., Ruske R., Pécsi M., Richter H., Altermann M. and Jäger K.D. (2007). Loess in Europe - its spatial distribution based on a European Loess Map, scale 1:2,500,000. Quaternary Science Reviews, 26, pp. 1301-1312. doi: https://doi.org/10.1016/j. quascirev.2007.02.003

IUSS Working Group WRB. (2015). World Reference Base for Soil Resources 2014, update 2015 International soil classification system for naming soils and creating legends for soil maps. World Soil Resources Reports No. 106. FAO, Rome.

Kemp R.A. (1999). Micromorphology of loess-paleosol sequences: a record of paleoenvironmental change. Catena 35(2-4), pp. 179-196. doi: https://doi.org/10.1016/ S0341-8162(98)00099-X

Kemp R.A. (2013). Paleosols and wind-blown sediments. Soil Micromorphology. In: Elias S.A., editor-in-chief. Reference Module in Earth Systems and Environmental Sciences. Encyclopedia of Quaternary Science (Second Edition). Elsevier, pp. 381-391.

Kovda I.V., Morgun E.G., Lebedeva M.P., Oleinik S.A. and Shishkov V.A. (2016). Identification of carbonate pedofeatures of different ages in modern chernozems. Eurasian Soil Science 49(7), pp. 807-823.

Kubiena W. (1938). Micropedology. Ames IA: Collegiate Press.

Lazukov G.I. and Chebatoreva N.S. (Eds.). (1977). Sections of the glacial deposits of the Center of the Russian Plain. Moscow: Moscow State University. (in Russian)

Lindbo D.L., Stolt M.H. and Vepraskas M.J. (2010). Redoximorphic Features. In: Stoops G., Marcelino V., Mees F., editors. Interpretation of micromorphological features of soils and regoliths. Amsterdam: Elsevier. pp. 129-147.

Markov K.K. (Ed.). (1977). Sections of glacial deposits in the center of the Russian Plain. Moscow: Moscow State University press. (in Russian) 
Little E.C., Lian O.B., Velichko A.A., Morozova T.D., Nechaev V.P., Dlussky K.G. and Rutter N.W. (2002). Quaternary stratigraphy and optical dating of loess from the East European Plain (Russia). Quaternary Science Reviews, 21, pp. 1745-1762. doi: https://doi.org/10.1016/ S0277-3791(01)00151-2

Matvishina J.N. (1982). Micromorphology of Pleistocene Soils of the Ukraine. Kiev. Sci. dumka. (in Russian)

Mehra O.P. and Jackson M.L. (1960). Iron oxide removal from soils and clays by a dithionite citrate system buffered with sodium bicarbonate. Clays and Clay Minerals, 7, pp. 317-327.

Minashina N.G. and Shishov L.L. (2002). Gypsum-containing soils: their distribution, genesis, and classification. Eurasian Soil Science, 35(3), pp. 240-247.

Morozova T.D. (1965). Micromorphological characteristics of pale yellow permafrost soils of Central Yakoutia in relation to cryogenesis. Sov. Soil Science, 7, pp. 1333.

Morozova T.D. (1981). The development of the soil cover of Europe in the Late Pleistocene. Moscow: Nauka. (in Russian)

Morozova T.D. (1995). Identification of paleosol types and their applicability for paleoclimatic reconstructions. GeoJournal, 36(2-3), pp. 199-205.

Nettleton W.D., Olson C.G. and Wysocki D.A. (2000). Paleosol classification: Problems and solutions. Catena, 41(1-3), pp. 61-92. doi: https://doi.org/10.1016/S0341-8162(00)00109-0

Novenko E.Yu., Zuganova I.S. and Koslov D.N. (2008). Evolution of Vegetation Cover in Late Pleistocene within the Central State Reserve Region. Izvestiya RAN Seriya Geograficheskaya, 1, pp. 87-99. (in Russian)

Panin P.G. (2007). Specificity of the morphology of interglacial and interstadial paleosol complexes of the middle and late Pleistocene in the center of the East European Plain. Eurasian Soil Science, 40(2), pp. 126-139.

Panin P.G. (2015). Paleosoils as an Indicator of Climate Change in the Late and Middle Pleistocene of the Center of the East European Plain. Izvestiya RAN Seriya Geograficheskaya, 5, pp. 69-82. (in Russian)

Panin P.G., Timireva S.N., Morozova T.D., Kononov Yu.M., and Velichko A.A. (2018). Morphology and micromorphology of the loess-paleosol sequences in the south of the East European plain (MIS 1-MIS 17). Catena, 168, pp. 79-101. doi: https://doi.org/10.1016/j. catena.2018.01.032

Poch R.M., Artieda O., Herrero J. and Lebedeva-Verba M. (2010). Gypsic Features In: Stoops G., Marcelino V., Mees F., editors. Interpretation of micromorphological features of soils and regoliths. pp. 195-216.

Rastvorova O.G., Andreev D.P., Gagarina E.l., Kasatkina G.A. and Fedorova N.N. (1995). Chemical analysis of soils. St. Petersburg: University. (in Russian)

Rozanov B.G. (2004). Soil Morphology. Moscow: Akademicheskii Proekt. (in Russian)

Rusakov A.V. and Korkka M.A. (2004). The Bryansk fossil soil of the extraglacial zone of the Valday glaciations as an indicator of landscape and soil forming processes in the center of the Russian Plain. Revista Mexicana De Ciencias Geologicas, 21(1), pp. 94-100. 
Ryskov Ya.G., Velichko A.A., Nikolaev V.I., Oleinik S.A., Timireva S.N., Nechaev V.P., Panin P.G. and Morozova T.D. (2008). Eurasian Soil Science, 41(9), pp. 937-945.

Sedov S., Rusakov A., Sheinkman V. and Korkka M. (2016). MIS3 paleosols in the centernorth of Eastern Europe and Western Siberia: Reductomorphic pedogenesis conditioned by permafrost? Catena, 146, pp. 38-47. doi: https://doi.org/10.1016/j.catena.2016.03.022

Stoops G. (2003). Guidelines for Analysis and Description of Soil and Regolith Thin Sections. Soil Science Society of America. Madison. Wisconsin.

Świtoniak M., Charzyński P., (Eds). (2014). Soil Sequences Atlas. Nicolaus Copernicus University press.

Sycheva S. and Khokhlova O. (2016). Genesis, 14C age, and duration of development of the Bryansk paleosol on the Central Russian Upland based on dating of different materials. Quaternary International, 399, pp. 111-121. doi: https://doi.org/10.1016/j. quaint.2015.08.055

Sycheva S.A., Sedov S.N., Bronnikova M.A., Targulian V.O. and Solleiro-Rebolledo E. (2017). Genesis, evolution, and catastrophic burying of the ryshkovo paleosol of the mikulino interglacial (mis 5e). Eurasian Soil Science, 9, pp. 1027-1046.

Sycheva S.A. and Sedov S.N. (2012). Paleopedogenesis during the Mikulino interglacial (MIS 5e) in the East-European plain: buried toposequence of the key-section «Alexandrov quarry». Boletin de la Sociedad Geologica Mexicana, 64(2), pp.189-197.

Sycheva S.A. (1998). New Data on the Composition and Evolution of the Mezin LoessPaleosol Complex in the Russian Plain. Eurasian Soil Science, 31(10), pp. 1177-1189.

Tabor N.J., Myers T.S. and Michel L.A. (2017). Sedimentologist's guide for recognition, description, and classification of paleosols. In: Zeigler K.E., Parker W.G., editors. Terrestrial Depositional Systems. Deciphering complexities through multiple stratigraphic methods. p. $165-208$.

Tamm O. (1922). Eine Methode zur Bestimmung der anorganischen Komponenten des Gelkomplexes im Boden. Medd. Statens skogsforsoksanstalt 19, pp. 385-404.

Todisco D. and Bhiry N. (2008). Micromorphology of periglacial sediments from the Tayara site, Qikirtaq Island, Nunavik (Canada). Catena, 76, pp. 1-21. doi: https://doi.org/10.1016/j. catena.2008.08.002

Van Vliet-Lanoë B. (1998). Frost and soils: implications for palaeosols, palaeo-climates and stratigraphy. Catena, 34, pp. 157-183.

Van Vliet-Lanoë B. (2010). Frost Action. In: Stoops G., Marcelino V., Mees F., editors. Interpretation of micromorphological features of soils and regoliths. Amsterdam: Elsevier. pp. 81-108.

Velichko A.A., Borisova O.K., Zakharov A.L., Kononov Yu.M., Konstantinov E.A., Kurbanov R.N., Morozova T.D., Panin P.G. and Timireva S.N. (2017a). Landscape changes in the Southern Russian Plain in the Late Pleistocene a case study of the loess-soil sequence in the Azov Sea Region. Izvestiya RAN Seriya Geograficheskaya, 1, pp. 74-83. (in Russian) 
Velichko A.A., Faustova M.A., Pisareva V.V., Gribchenko Yu.N., Sudakova N.G., and Lavrentiev N.V. (2011). Chapter 26 - Glaciations of the East European Plain: Distribution and Chronology. In: Ehlers J., Gibbard P.L., Hughes P.D., editors. Developments in Quaternary Sciences, 15, pp. 337-359. doi: 10.1016/B978-0-444-53447-7.00026-X ISSN: 1571-0866, \# 2011 Elsevier B.V.

Velichko A.A., Gribchenko Y.N., Drenova A.N., Morozova T.D. and Timireva S.N. (1997). Soil section Gunki. In: Velichko A.A., editor. Loess-soil formation East-European plain. Paleogeography and stratigraphy. Moscow: Institute of Geography, Russian Academy of Science, pp. 60-79. (in Russian)

Velichko A.A. and Khalcheva T.A. (1982). Late Pleistocene loesses and their spatial distribution (map 3 - Loess cover during Valdai ice age). In: Velichko A.A., Gerasimov I.P., editors. Paleogeography of Europe during the last hundred thousand years (atlasmonograph) Moscow: Nauka. pp. 70-74. (in Russian)

Velichko A.A., Morozova T.D., NechaevV.P. and Porozhnyakova O.M. (1996). Paleocryogenesis, soil cover and agriculture. Moscow: Nauka. (in Russian)

Velichko A.A., MorozovaT.D. and Panin P.G. (2007). Soil polygenetic complexes as a systematic phenomenon of Pleistocene macrocycles. Izvestiya RAN Seriya Geograficheskaya, 2, pp. 44-54. (in Russian)

Velichko A.A., Morozova T.D. and Udartsev V.P. (1985). General and regional properties of the Middle and Late Pleistocene loess strata of the Russian Plain. In: The theory of cyclicity of loesses in the practice of engineering and geological surveys. Moscow: Nauka. pp. 9098. (in Russian)

Velichko A.A. and Morozova T.D. (1963). Mikulino paleosol, its features and stratigraphic significance. In: Neustadt M.I., editor. Anthropogen of the Russian Plain and its stratigraphic components. Moscow: USSR Academy of Sciences Press. pp. 100-146. (in Russian)

Velichko A.A. and Morozova T.D. (1972). The main horizons of loess and fossil soils of the Russian Plain. In: Velichko A.A., editor. Loesses, paleosols and cryogenic phenomena on the Russian Plain. Moscow: Nauka. pp. 5-25. (in Russian)

Velichko A.A. and Morozova T.D. (2010). Basic features of Late Pleistocene soil formation in the East European Plain and their paleogeographic interpretation. Eurasian Soil Science, 43(13), pp. 1535-1546.

Velichko A.A. and Morozova T.D. (2015). Main features of soil formation within the Pleistocene on the East European Plane and their paleogeographical. In: Kudeyarov V.N., Ivanov I.V., editors. Evolution of soil and soil cover. Theory, diversity of natural evolution and antropogenic transformations of soil. Moscow: GEOS. pp. 321-337. (in Russian)

Velichko A.A., Semenov V.V., Pospelova G.A., Morozova T.D., Nechaev V.P., Gribchenko Y.N., Dlussky K.G., Rutter N.W., Catto N.R. and Little E.C. (2006). Matuyama-Brunhes boundary in key sections of the loess-paleosol-glacial formations on the East European Plain. Quaternary International, 152-153, pp. 94-102. doi: https://doi.org/10.1016/j. quaint.2005.12.018

Velichko A.A., Timireva S.N. and Khalcheva T.A. (1994). Late Pleistocene loessts of periglacial areas of the western Russian Plain. In: Velichko A.A., Starkel L., editors. Paleogeographic basis of the modern landscapes. Moscow: Nauka. pp. 63-69. (in Russian) 
Velichko A.A., Yang T., Alekseev A.O., Borisova O.K., Kalinin P.I., Konishchev V.N., Kononov Yu.M., Konstantinov E.A., Kurbanov R.N., Panin P.G., Rogov V.V., Sarana V.A., Timireva S.N. and Chubarov I.G. (2017b). A comparative analysis of changing sedimentation conditions during the last interglacial-glacial macrocycle in the loess areas of the southern East European Plain (the Azov Sea region) and Central China (Loess Plateau). Geomorphology, 1, pp. 3-18. (in Russian)

Velichko A.A., Zelikson E.M., Borisova O.K., Gribchenko Y.N., Morozova T.D. and Nechaev V.P. (2004). Quantitative climate reconstructions of East-European plain for the last 450 thousand years. Izvestiya RAN Seriya Geograficheskaya, 1, pp. 7-25. (in Russian with English abstract)

Velichko A.A. (Ed.). (2002). Dynamics of terrestrial landscape components and inner marine basins of Northern Eurasia during the last 130000 years. Atlas-monography «Evolution of landscapes and climates of Northern Eurasia. Late Pleistocene - Holocene - elements of prognosis. II. General paleogeography». Moscow: GEOS. (in Russian)

Villagran X.S., Schaefer C.E.G.R. and Ligouis B. (2013). Living in the cold: Geoarchaeology of sealing sites from Byers Peninsula (Livingston Island, Antarctica). Quaternary International, 27, pp. 184-199. doi: https://doi.org/10.1016/j.quaint.2013.07.001

Virina E.I., Heller F., Faustov S.S., Bolikhovskaya N.S., Krasnenkov R.V., Gendler T., Hailwood E.A. and Hus J. (2000). Palaeoclimatic record in the loess-palaeosol sequence of the Strelitsa type section (Don glaciation area, Russia) deduced from rock magnetic and palynological data. Journal of Quaternary Science, 15(5), pp. 487-499.

Yakimenko E.Y. (1995). Pleistocene paleosols in the loess and loess-like sediments of the Central part of the Russian Plain. Quaternary Science Reviews, 14, pp. 747-753. doi: https:// doi.org/10.1016/0277-3791(95)00049-6

Zaidel'man F.R. and Nikiforova A.S. (2010). Ferromanganese concretionary neoformations: A review. Eurasian Soil Science, 43(3), pp. 248-258.

Zykin V.S. and Zykina V.S. (2015). The Middle and Late Pleistocene loess-soil record in the Iskitim area of Novosibirsk Priobie, south-eastern West Siberia. Quaternary International, 365, pp. 15-25. 